\title{
Consumption of Modern Furniture as a Strategy of Distinction in Turkey
}

\author{
Meltem Ö. Gürel
}

This study scrutinizes consumption of modern design as a strategy of distinction in Turkey. Conceptualizing taste as an acquired and dynamic medium through which inhabitants build and sustain social relationships, the article examines domestic furnishings as tools for constructing a Western socio-cultural difference from the late nineteenth century through to the 1950 s and 1960s. Furthermore, it looks at the structures acting on furniture design and consumer choices. The study explicates the view that architects and decorators promoted a taste reform towards different versions of European Modernism throughout the 1930s and in the mid-twentieth century. The modern emerged as a distinctive element, not just between different classes but also within upper-class consumers themselves. The luxurious hotel projects, particularly the pivotal Istanbul Hilton Hotel, were instrumental in spreading the codes of furniture and for shaping contemporary practices, when the influx of US culture had an all-pervading impact, in the post Second World War context. A shift in the dominant taste towards modern designs, the use of synthetic materials, such as Formica, and the advent of new design elements, such as the American bar, revealed a concern for taking part in a new modern identity that reflected cultural competence in the way the West was (re)interpreted.

Keywords: domestic material culture-furniture-identity-Istanbul Hilton Hotel-modern design-taste

Home furnishings have been instrumental in constructing, sustaining and transforming Western identities and modern socio-cultural distinction in Turkey. In the late nineteenth century, the incorporation of Western furniture in the elite domestic space reflected social changes and the desire for Westernization. This desire was intensified and widened after the foundation of the Turkish Republic. Modern style was promoted to build contemporary identities. This article examines connotations of home furnishings by exploring the structures acting on the developments in furniture design from the late nineteenth century through the mid-twentieth century. The key question is how was modern design, in its plurality and complexity, promoted and received in Turkey? I address this question in the context of the 1930s, when the Modern Movement, which developed in Europe in the interwar era, had a bearing on the Turkish architectural and design culture. The focus is the 1950s and 1960s, when the influx of US culture and different or arguably contradictory versions of modernism had an all-pervading impact, in the post Second World War context. This impact brought out new design elements and practices, such as the 'American bar' and the use of plastic materials, such as Formica. These elements and the consumption of modern designs are scrutinized through case studies of residential interiors and the Istanbul Hilton Hotel, which widely influenced the design of these interiors and the dominating taste. This analysis embraces the idea that a piece of furniture's material qualities, physical expression and style-that is, the visible sign of the unity of a culture, as defined by Meyer Schapiro-represent a collective taste. ${ }^{1}$ They communicate codes meaningful to a culture or to a group of people who are interconnected by shared values and a common ideology. ${ }^{2}$ An individual's preferences in equipping the domestic realm do not merely indicate distinctive personal preferences. Rather, they reflect group belonging and, significantly, embody an acquired taste informed by the total conceptual environment of a person: what Pierre Bourdieu calls 'habitus'. ${ }^{3}$ Comprising past experiences, concepts, beliefs, education and 
'dispositions', habitus foreshadows personal choices and thus challenges the concept of 'free will'. ${ }^{4}$ Consumers' choices, or what they prefer to display in their domestic space, are means through which they build and sustain social relationships. These choices represent inhabitants' 'cultural capital', referring to socially and culturally valued tastes. ${ }^{5}$ The availability of cultural capital depends on various conditions, such as class and education, and its accessibility to different social groups fluctuates. Hence, embodied in the material qualities of home furnishings is distinction. This notion can explain the desire for Western furniture in Turkish society. It requires a closer engagement with the dynamic capacity of habitus and cultural capital, however, to explain how the modern style as well as new furniture trends and materials became distinctive elements, not just between different classes but also within the same socio-economic group. How did the notion of distinction as difference, suggesting the distinguished, facilitate the consumption of modern designs in the Turkish context?

\section{Implications of Western furniture in the Turkish context: A historical outlook}

The very mobile element of furniture paradoxically connotes an immobile lifestyle: one that indicates stability and civilization. Furniture complements architecture in the formation of life spaces; it is also perceived as one of the building blocks of an elevated life, as is architecture. In the Turkish context, the perception of freestanding furniture as a symbol of civilization can be traced to its emergence in the elite Ottoman interiors of the nineteenth century, as part of the process of westernization. ${ }^{6}$ Initially, occidental furniture was adapted to the interiors of the Dolmabahçe (1842-1856) and Beylerbeyi Palaces (1861-1865), as a complement to their eclectic architectural styles. The architecture and decorative programme of Dolmabahçe Palace signalled an ideological shift from the golden ages of the Ottoman Empire. ${ }^{7}$ Unlike the Topkap Palace, which was built during the rise of the Empire, Dolmabahçe reflected the changing political structure following the reorganization reforms of $1839 .{ }^{8}$ Its freestanding Western furniture marked a divergence from that of the indigenous houses and the Topkapı Palace. Traditional interiors had built-in furniture, such as a low divan called a sedir, and shelves and closets that were an integral part of the structure. The emptied interiors were accoutred with cushions, pillows and textiles. Freestanding furniture was limited to chests, cradles, stools and the like. ${ }^{9}$

Around the turn of the twentieth century, furniture styles reflected the latest trends in Europe. Among them was Art Nouveau, as manifested in the apartment buildings in Pera and residences along the Bosporus, designed by the Italian architect Raimondo d'Aronco. ${ }^{10}$ Bureaucrats were the first to include European furniture in their homes. ${ }^{11}$ The wealthy non-Muslim population in the port cities, such as Istanbul and Izmir, constituted an important group of customers in the market. ${ }^{12}$ They were also heavily involved with the supply of furniture by either importing or manufacturing it. According to Ottoman industry statistics, between 1913 and 1915 all the big furniture manufacturers were located in Istanbul. ${ }^{13}$ European furniture helped the Ottoman elite to build a Western identity. The piano was the object par excellence, denoting an occidental social standing in the living room of the privileged. In both the late Ottoman and the ensuing early republican upper-class home, the piano implied the educational level of the household's female members. ${ }^{14}$

After the Ottoman rule officially came to an end, and the Turkish Republic was founded in 1923, the metaphorical position of Western furniture reached new dimensions. More than signifying an occidental socio-cultural distinction for the elite, Western furniture was appropriated for the citizens of the new nation, firmly aligned with the Occident. Republican reforms revolutionized the ideas of family and home. Western furniture was internalized as a setting for a 'civilized' life. Such furniture was 
Fig 1. An interior design proposal with unadorned furniture, lighting fixtures and accessories by Aptullah Ziya, 1931. Mimar, vol. 1, no. 1, 1931. presented in the 1930s elementary school books, aiming to teach the children the qualities of a contemporary home, according to European precedents. ${ }^{15}$ Architects were among those who envisioned domestic designs and furnishings as instruments of social engineering. As an influential republican architect put it, in rural domestic interiors, this entailed the need to 'familiarize beds to those villagers who are used to sleeping together on earthen floors, to teach chairs to those who sit on the floor, to supply tables for those who eat on the floors' and 'to revolutionize lifestyles'. ${ }^{16}$

Throughout the 1930s, modern architecture and furniture design were associated with the concepts of progress, youth, health and social emancipation, which were important to the republican revolutions. They were promoted to separate the young nation from the past and to build a national identity in line with the republican ideology. Nestled in this ideology, architects produced residential designs, distinguished by the formal qualities of the Modern Movement and furniture, characterized by geometric forms, sleek surfaces and metal elements. ${ }^{17}$ In popular jargon, this was called 'cubic'. By the mid-1930s, the modernist idea of furniture as an integral part of architecture was popularized by prominent Turkish architects as well as magazines, such as Muhit and Yedigün. ${ }^{18}$ Influential designers, including Le Corbusier, as well as Ernst Egli and Bruno Taut, both of whom worked and taught in Turkey, Congres Internationaux d'Architecture Moderne (CIAM, 1928-1959) and the Bauhaus, had an impact on Turkish modernism with respect to furnishings and the concept of 'total design'. ${ }^{19}$ Traces of this impact can be seen in Aptullah Ziya's inaugural interior perspectives, published in the first issue of Mimar(1931). ${ }^{20}$ These illustrations showed sleek interiors, with a piano-the ultimate symbol of westernization-and were aimed at encouraging professionals to adopt modern designs [1]. Celal Esat Arseven wrote about new furniture in a new house in his seminal book Yeni Mimari (New Architecture, 1931), in which he promoted functional furniture in the modern home. According to Arseven, both functional design and furniture layout were tasks for the architect. ${ }^{21}$

The modern style was also evident in the work of decorators. ${ }^{22}$ Sketches by decorator Nizami Bey published in Mimar (1931) are remarkable not only for promoting

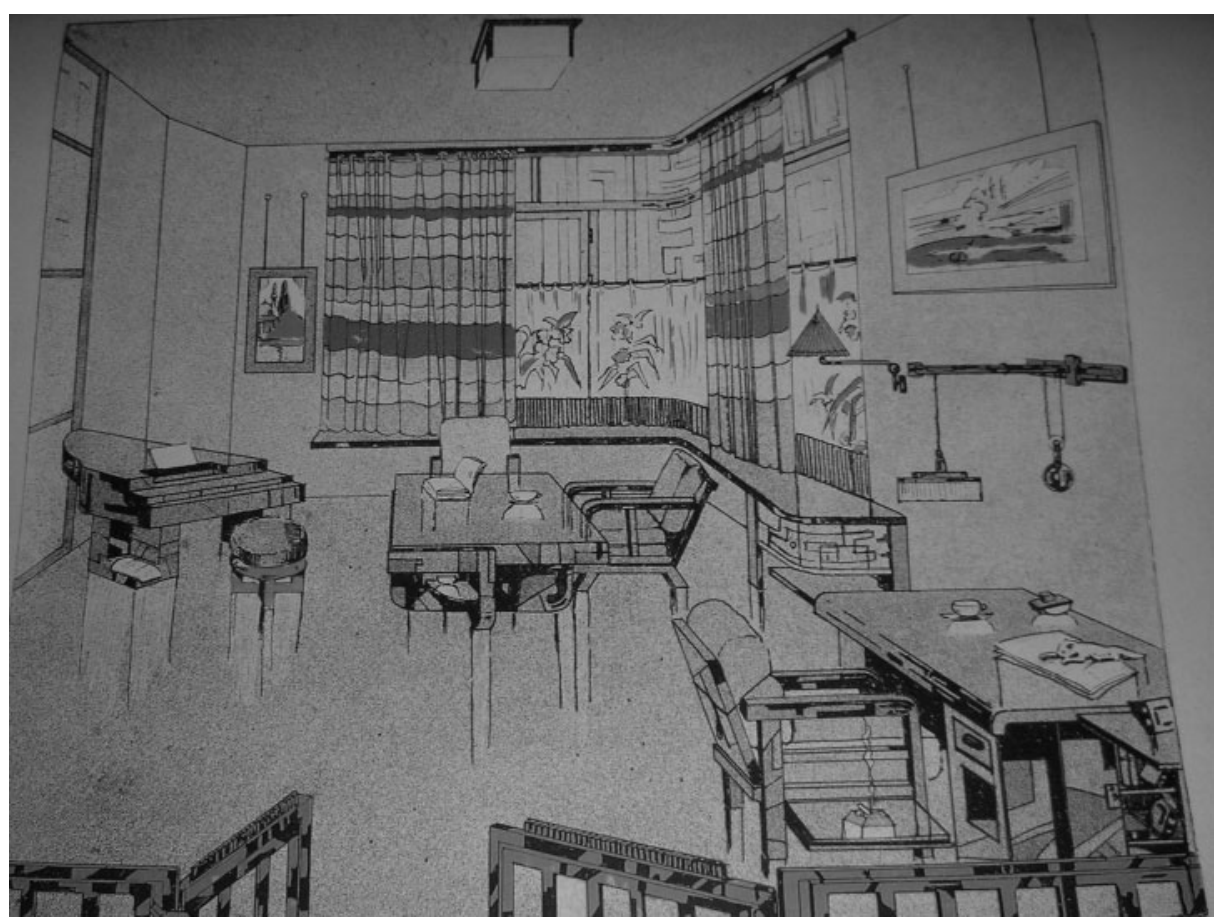


modern interior design but also for revealing the gendered way of thinking of the Paris-educated designer. A room proposed for the use of 'an architect' - a typical male occupation - contained built-in and tubular steel furniture; however, a bedroom designed for 'a rich woman' was furnished in Art Deco style with a curvilinear bedroom set [2]. 'Cubic' furniture of the 1930s can be read as a fusion of these two styles into furniture characterized by cubic forms and planer aesthetics. ${ }^{23}$ Modern works of decorators were also exhibited in film sets. In a commentary published in Mimar (1932), architect Abidin Mortaş addressed the significance of these decors in exhibiting and disseminating 'correct' choices of furnishings to the public [3].24

A number of well-known literary works of the era described modern residences and forms of furniture as instruments of social transformation. They also pondered the power of furniture in seeking distinction and the paradoxes this evoked against an accustomed way of life. ${ }^{25}$ This idea is remarkably exposed in Ankara (1934), a novel written by Yakup Kadri Karaosmanoğlu:

Like every matter, Hakkı Bey took the concept of the house a little further and showed the first example of cubic architecture to other people. The first such building with entirely glass corners, lacquered doors, and coved ceilings with hidden electrical installations was Hakkı Bey's house. Mrs. Selma's husband took a hidden pride in this. Particularly on days when he first showed the rooms and parlours, furnished according to pictures in the latest exhibition catalogues from Paris or Berlin, he was like a child, thrilled with his new holiday clothes. ${ }^{26}$
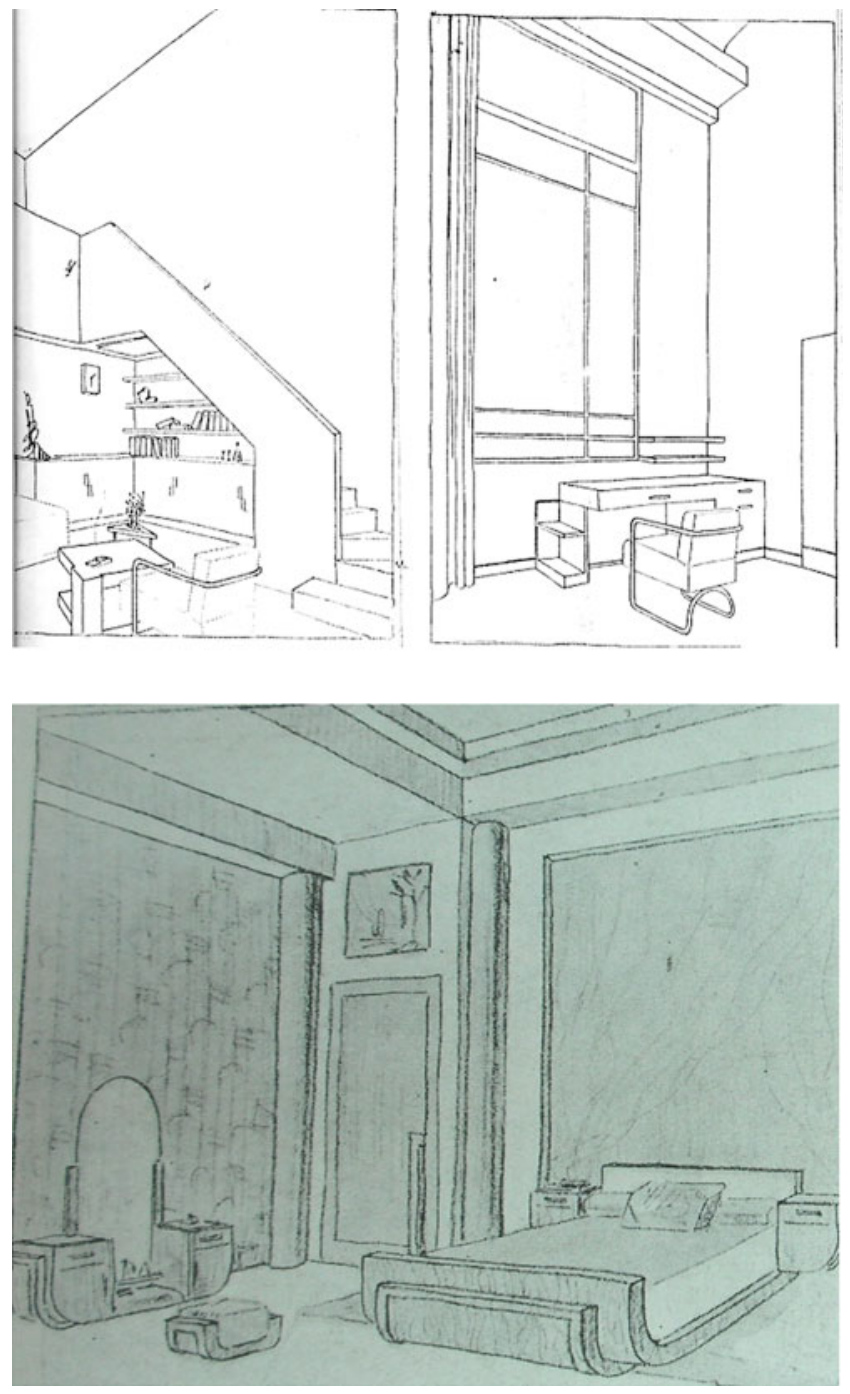

Here, Hakkı Bey represents an elite group whose aesthetic preferences help them to express and legitimize their collective social and cultural difference. Their consumption of modern design is grounded in their 'cultural capital', which is, as Bourdieu, suggests neither natural nor static. ${ }^{27}$ Rather, it has the capacity to transform continuously. Hidden in this dynamic quality, we can locate a strategy of power that defines and refigures boundaries. Modern furniture, in the republican context, not only serves to define a Western social standing (as furniture did in the late Ottoman context) but also serves to distinguish a civic posi-

Fig 2. Decorator Nizami Bey's sketches. A room for 'an architect' - a typical male occupation-contains built-in, planer and tubular steel furniture; a bedroom designed for 'a rich woman' is furnished in Art Deco style with curved forms. Mimar, no. 5, 1932, p. 144 and p. 146 tion associated with the young republic. Modern designs operate as agencies of the young nation's progressive ideals that depart from the past. Hence, they embody layers of meaning, as objects of a distinguished social status, of national pride, of cultural development and of contemporary transformation in the domestic interior landscape. Modern furniture is also associated with upper income levels. The words of Lüküs Hayat (Luxurious Life, 1933), the first Turkish operetta, written and composed by Ekrem and Cemal Reşit Rey, perhaps best express this class association:

An apartment in Şişli

If not, you are not nifty

Nickel and cubic furniture

On the wall an oil painting picture ... 


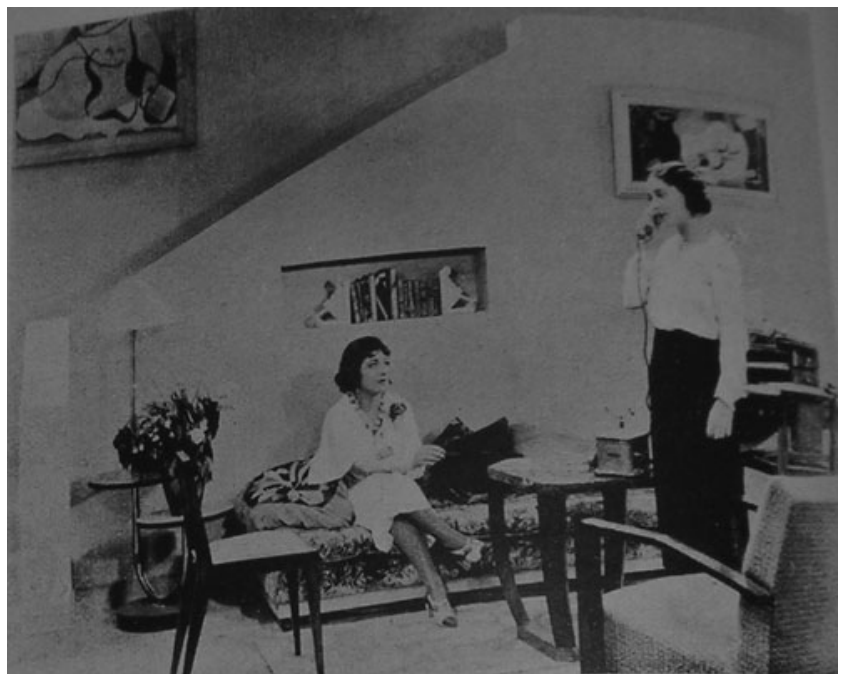

Fig 3. Set design for the film Istanbul Streets by Vedat Ömer Ar. Architect A. Mortaş praised the film décor for exhibiting and disseminating 'correct' choices of interior furnishings to the public. Mimar, no. 2, 1932, p. 48
Nonetheless, the reception of modern furniture as an element of distinction was limited, even among upper-class early republican citizens. Modern aesthetics evoked ambivalent feelings. Many did not prefer modern furniture, even when they moved to new 'cubic' homes. These were often filled with either inherited or bought furniture, in tune with nineteenth-century European styles. ${ }^{28}$ This was partly because many considered modern designs to be cold, bare and even alien. Such sentiments can be read in Karaosmanoğlu's Ankara:

Armchairs reminiscent of dentists' chairs, couches that look like operating tables, sofas like the interiors of automobiles, octagonal tables, cupboards that do not differ from old grain storage bins, display units and at last some dreadful and strange bibelots that are scattered on these; naked wall, naked floor ... a cold clinical gloss on all of them...29

These opinions reflect the criticisms voiced by influential opponents of the modern style. Among them was the French artist Marie Louis Sue, who served as the director of the Decorative Arts Department in the Academy of Fine Arts from 1939 to 1943. In his inaugural lecture and in a published article (Yedigün, 1940), Sue opposed these austere aesthetics as machinelike and unnatural and asked his students to search for 'a modern national style'. ${ }^{30}$ This inclination matched the architectural pedagogy during the 1940s. ${ }^{31}$ Its most famous proponent was the architect and educator, Sedad Hakkı Eldem, whose work is marked by a lifelong quest for a fusion of modern and traditional forms. The perception of modern furniture as 'uncomfortable', 'cold', 'naked' and 'clinical' echoes its widespread reception elsewhere, and it relates to the well-known criticisms of interwar modernism in general. ${ }^{32}$ These criticisms addressed the response to modern furniture-conceptualized as an integral part of the architectural shell-as an invasion of the personal character of the home. But, how much of the personal character of home furnishings is personal?

\section{Parameters of furniture production and consumption in the mid-twentieth century}

Aside from practical reasons, consumption or dismissal of modern furniture in new homes can be explained as a strategy of distinction, serving to affirm status. ${ }^{33}$ One of the reasons why a fraction of the dominant class did not prefer modern furniture reflects a concern for diverging from the European tradition: ${ }^{34}$ historical styles helped their owners to express their connection to the Western tradition rooted in the late Ottoman aristocratic taste. This strategy prevailed throughout the first half of the 1950s. Furniture characterized by a neoclassical European style dominated taste [4]. ${ }^{35}$ Within the confines of the home, this was most visible in the living and dining areas, where social interactions among the inhabitants and their guests took place. ${ }^{36}$ These spaces mediate between the personal and the public aspects of the home. They form the location where the inhabitant's identity is portrayed to outsiders. The representative quality manifested through material culture conveys messages and symbolic meanings that reflect the inhabitant's habitus. Visual codes are, in many ways, intricate in themselves. They include, but are not limited to social, class, gender and civic identities. Thus, this is where the inclusions and exclusions that service distinction are most pronounced. This idea of the 1950s reception areas as status symbols can be inferred from 
Orhan Pamuk's Istanbul: Memories and the City (his story of the city and of his childhood and youth).

Not only were pianos not played but there were other things-always-locked glass sideboards stuffed with Chinese porcelain, cups, silver sets ... all these things filling the living rooms of each apartment made me feel that they were displayed not for life, but for death.

When we harshly sat on couches with inlaid mother-of-pearl and silver strings, our grandmother warned us, 'Sit appropriately'. Living rooms were set up as little museums for visitors-some of which were imaginary-whose arrival time was uncertain, rather than as comfortable spaces where the inhabitants could pass time in peace, such was the concern for westernization. ${ }^{37}$

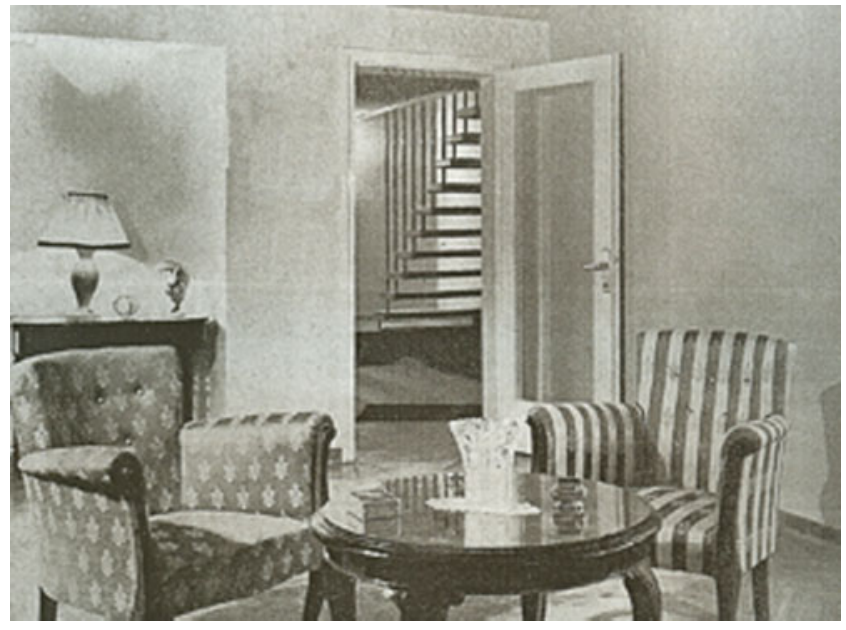

Fig 4. Stylish furniture of the early 1950s. Arkitekt, no. 269 70-71-272, 1954, pp. 57-9

What Pamuk calls a museum living room, crammed with eclectic furniture and accessories, represents the reception areas of high-income families in Istanbul and other major cosmopolitan cities, during the 1950s. His analysis evokes the same sense of distaste for the crowded homes that can be found in the writings of Le Corbusier. ${ }^{38}$ His critical observation of the bourgeois interior as a cultural reflection echoes the work of the literary critic Walter Benjamin in Paris, Capital of the Nineteenth Century. ${ }^{39}$ The desire for storing and displaying luxurious goods and historical styles in the most visible part of the home empowers bourgeois aspirations for European socio-cultural distinction and for the development of a capitalist culture.

Throughout the first half of the 1950s, furniture's historical overtones were adapted from European catalogues; these overtones were referred to as 'classical style'. Antique, caned and Art Nouveau pieces inherited from earlier periods also decorated the homes of the dominant classes, especially those with European connections. Istanbul continued its position as the hub of furniture production. The non-Muslim population dominated this business. The Maison Psalty of Beyoğlu, which was opened in 1867 by Jean Psalty, closed in 1952.40 As Giovanni Scognamillo wrote, imitations of European antiques were in demand: the Dekorasyon furniture gallery in Beyoğlu, 'displayed little furniture in its windows, for example, a couch upholstered in brocade, a coffee table coated with mother-of-pearl, a dresser and the like. But each of them was a style of its own, was an antique'. ${ }^{41}$ Scognamillo noted, however, that all these antiques were actually well-made imitations by an Italian decorator from Florence. The repertoire of such furniture stores affected consumers' preferences. Addressing the dominance of eclectic furniture before the mid-1950s, Eldem wrote, 'Antiques and their imitation have been much preferred ... Gilded, caned ... furniture [was] still in demand. Antique stores [were] in command of the market and taste'. ${ }^{42}$

Such furniture was a commodity for upper-income groups in the 1950s. Production increased with the proliferation of new shops and new carpenters, some of whom learnt the basics of the art from non-Muslim masters. This production, however, was not geared towards the lower to middle classes. As one furniture maker put it, 'most people sat on plain sedir'. ${ }^{43}$ An average person's choices were influenced mostly by availability and cost. Chic furniture certainly was not restricted to the elite, as it had been around the turn of the century; yet, it was still perceived as a luxury. 


\section{A shift in the dominant taste}

The underdevelopment of furniture production for middle to low-income groups was addressed in Arkitekt, the most influential architectural journal of the time. A 1948 commentary tied this trend to a material deficit in the market. The text also emphasized the architect's role in furniture production, highlighting modern designs by architects, including Marcel Breuer, Alvar Aalto and Charles Eames. In a 1950 issue, Zeki Sayar, the publisher of the journal, declared, 'Comfortable, sturdy and tasteful furniture cannot be made in our country. Our native furniture is not at all satisfactory'. ${ }^{44}$ Sayar stated that furniture makers at the time copied models from design catalogues brought from other countries because 'decorators involved with furniture were extremely few in number'. The country had neither the factories nor the technical resources to mass-produce furniture. Criticizing the building inducement law (number 5228) that exempted only pine timber from customs tax, he stressed the urgency of providing high-quality materials, such as kiln-dried wood, veneers and hardware, for furniture manufacture. Sayar presented 'the furniture matter' as an important national problem; like housing the Turkish masses, it needed the immediate attention of the government. 'Furniture in the old style' was limited in supply and, thus, expensive. To manufacture inexpensive furniture for everyone, Sayar endorsed the actions of the governments of France, Sweden and Holland. For him, Le Corbusier's interior and furniture designs in the Unité d'Habitation (1946-1952) in Marseilles provided a valuable precedent [5]. ${ }^{45}$

Sayar's views reflected the architectural culture that envisioned modern designs as the answer to the furniture problem. Yet, the promotion of modern designs cannot simply be connected to their conception as comfortable, functional, inexpensive and appropriate for the new living spaces. Architects, interior architects/decorators and artists promoted modern designs as a reform in taste. Their designs were in tune with the mid-century modern style. Chairs such as the Shell Chair (1951), the Pedestal Chair (1955) and the Womb Chair $(1946,1948)$ were celebrated as vanguard furniture designs, as were the forms and materials introduced by influential figures such as Charles and Ray Eames, Eero Saarinen, George Nelson and Harry Bertoia. The lightweight chair designs published in Arkitekt are examples of experiments with new forms and materials [6]. Such artistic forms gave primacy to the sculptural quality of a chair, rather than to economic considerations and functional requirements. A professional in Ankara explained the artistic inclinations and the role of decorators in d'Habitation by Le Corbusie (1946-1952). Arkitekt, no.

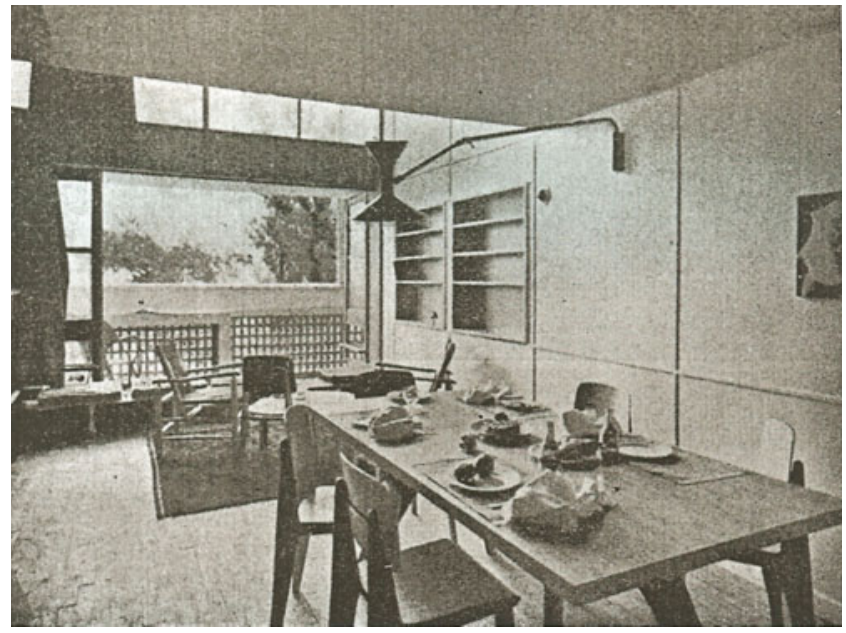

At that time, there was bad, carved, rustic style furniture. We manufactured furniture influenced by Danish furniture design. We had elite customers, who became good friends ... At that time very few people had the interior of their houses designed. People mostly bought furniture. Like most designers in Ankara, we sold furniture. ${ }^{46}$

For precursor designs, the most stylish store was Moderno in Istanbul, co-owned by an architect. ${ }^{47}$ The store was also a favourite stop for designers from Ankara and Izmir. In Ankara, Galeri Milar, also owned by an architect, was the most prominent address for modern furniture. The owner commissioned well-known Turkish architects to design the furniture sold in 
Ithxา Koman, beykeltrasi sahasın. doki fasliyetlerine muvazi olarak. plas. tic san'atlar sentezi anlayısındaki calısmałarıns đí, dekoratōr Sadi özis. ve bu grufa soa katılan haykeltraș Sadi Calıkla baraber devam etmektedir. Bu ü san'atkàrın vücuda getirmiş old’zkları fonksiyonel san'at eserleri, şchrimizin it>ri düşünceli çevrelerinde büyük bir

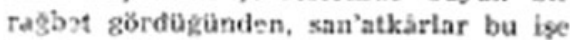
tahsis edilmis yenj bir atölye kurmus. lardir. Bu ndehrmuzda llhan Koman"in, 1958 de actlacak olan sinsanlık Hizme tindes mevzulu, Beynelmilet Brunxelles sergisi Türk Paviyonu önüne konulacak olan 16 metre yüksekligindeki heykelinis maketini ve grup balinde yapmis olduk. ları möbleleri neșrediyoruz.

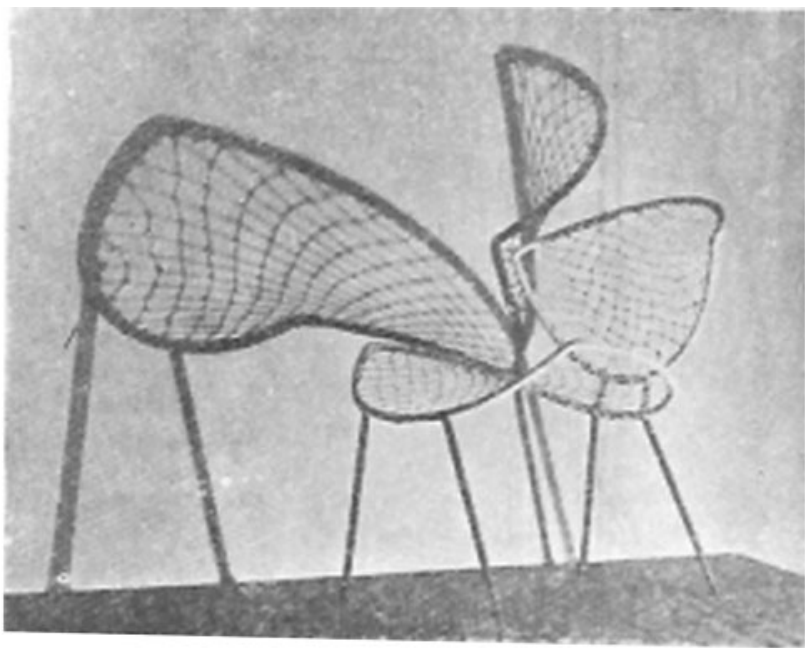

Boru v? ag̃du sandalya

i'ban KOMAN re Sadi Özis

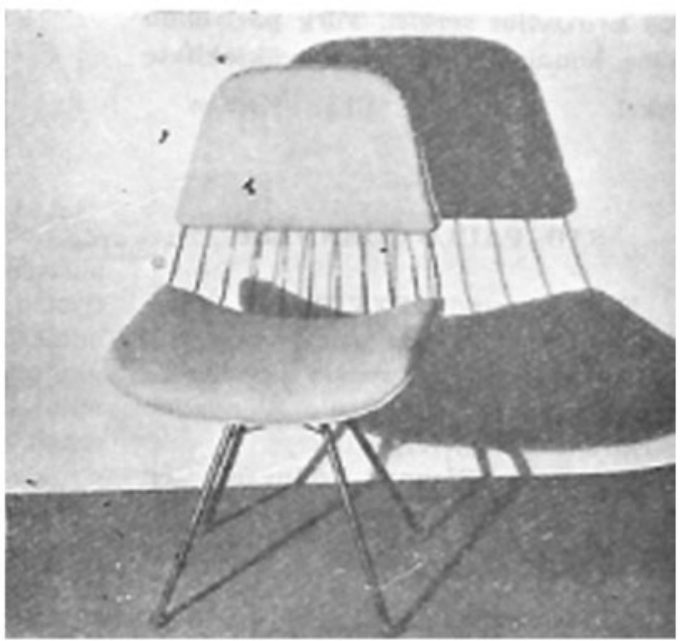

Fig 6. Modern chair designs by Sadi Özis, İlhan Koman and Sadi Calık. Airy chairs incorporated netting and metal pipes; stretched rope on a steel pipe frame; plastic on an iron skeleton. Arkitekt 26 , no. 286,1957 , p. 28
Modern furniture is the means to be comfortable. The modern house has happy colours, curved chairs, soft pillows and suggestive corners that invite us to sleep and let us forget about the narrowness that we experience ... The emptiness in the modern house is the primary condition of comfort. There is no way of breathing in a house filled with furniture. ${ }^{50}$

An endorsement of modern furniture as such recalls ideas of correct living promoted by architects and artists before the Second World War. A notable example is Le Corbusier's denunciation of bulky furniture as cluttering objects that fit neither the contemporary lifestyles nor modern interiors. ${ }^{51}$ Modern ideas for correct living disseminated after the Second World War through exhibitions, museums, catalogues, fairs, advertisements, films and model home designs. ${ }^{52}$ These venues aimed to reform public taste towards an acceptance of modern architecture and interior design. 53 
Towards the end of the 1950s and throughout the 1960s, there was a shift in dominant taste. Furniture characterized by linear elements, planar surfaces, new materials, metal, slanted legs and an unadorned look became popular. Considered fashionable, modern designs were utilized to create luxurious interiors. This shift from historical styles to modern designs in the preferences of the dominant classes, indicates a strategy of distinction. Modern designs were consumed as signifiers of a superior social standing related to the redefinition of the West. Thus, the mode of furniture provided a code or a common understanding that characterized the transformations of the Western sphere. ${ }^{54}$

\section{Consumption of the Modern as a Notion of Distinction}

\section{The Istanbul Hilton Hotel (1952-1955)}

An indisputable sign of the transformation in the way the West was understood and defined in Turkey was the Istanbul Hilton Hotel, built by the American architectural firm Skidmore, Owings \& Merrill in collaboration with Sedad Hakkı Eldem [7]. In the aftermath of the Second World War, the United States displaced Europe as the leading power of the West. ${ }^{55}$ The liberal policies of the Democrat Party government between 1950 and 1960 contributed to the conception of the United States as the manifestation of modernization. The construction of the hotel symbolized Turkey's aspiration to become, in Conrad Hilton's words, 'a "little America"'. The government offered Hilton 'full cooperation'. ${ }^{56}$ A prominent site, overlooking the Bosporus strait, was allocated for the building. Incidentally, the Turkish Republic Pension Fund paid for this pivotal project and other luxurious hotel buildings that followed this precedent. Simultaneously, the hotel marked the United States' political ambitions to Americanize the nation, which was considered vulnerable to the Communist threat. ${ }^{57}$ The post-war military and economic aid that extended to the country had a profound impact by spreading American influence from popular culture to education. ${ }^{58}$ Hilton characterized the hotel and the city, standing 'thirty miles from the Iron Curtain' as 'a tremendous place to plant a little bit of America'. ${ }^{59}$

Fig 7. The Istanbul Hilton Hotel (1952-1955) designed by SOM in collaboration with Sedad Hakkı Eldem. Photograph: (c) Ezra Stoller/Esto

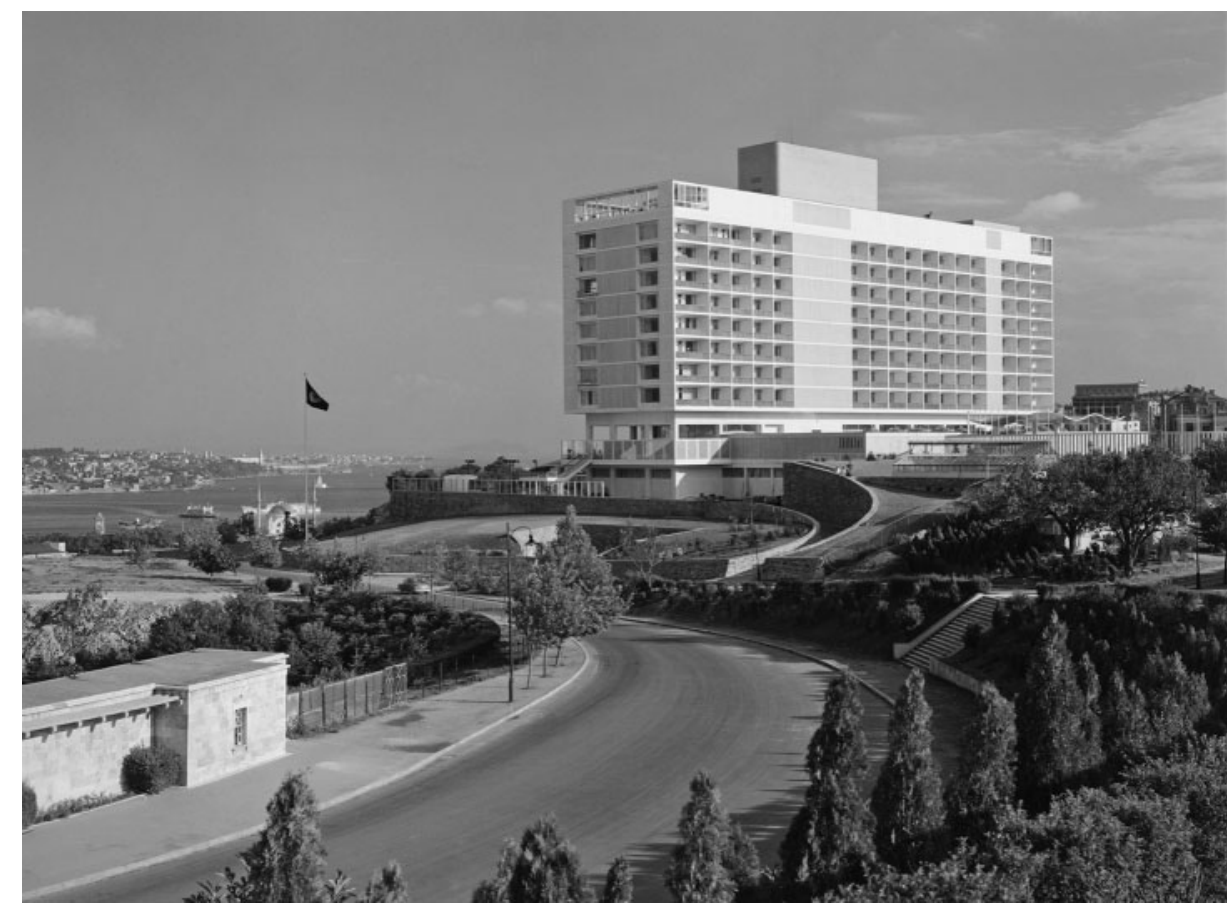


The US architectural press viewed the Istanbul Hilton as 'a good ambassador', showing the triumph of the 'U.S. architecture abroad'. ${ }^{60}$ The hotel was widely covered by national and international journals as a testimony to the continued Westernization of Turkey. ${ }^{61}$ Architectural Forum asserted:

To many Turks, who long ago discarded the fez and the veil in favour of Western ways, the new Istanbul Hilton symbolizes something else: the hope that Turkey, once called the 'sick man of Europe', will become a healthy, wealthy and much-visited member of the international family. ${ }^{62}$

The sleek concrete building designed under the direction of Gordon Bunshaft conformed to the formal characteristics of 'International Style'. ${ }^{63}$ Bunshaft had been to Turkey on assignment from the Turkish government for a Marshall Plan housing and town planning survey. ${ }^{64}$

The Hilton was featured in the popular Turkish press as exemplifying the high art of building culture as well as being a favourite meeting site for Istanbul's high society. ${ }^{65}$ The luxurious hotel was a preferred stop for dining, entertainment, parties, weddings and even for Turkish couples on their honeymoons. ${ }^{66}$ The suburban landscape, characterized by pools, grass and shrubbery, and the comfortable interiors, equipped with comfort systems, air conditioning and chic furnishings, represented all the amenities the capitalist West had to offer.

According to Eldem, the interior architecture of the hotel marked a turning point in furniture modes; it provoked a shift to modern taste in home decoration. Eldem argued that an inclination towards carved furniture had 'lasted for years until the Hilton Hotel was built. The decoration of this hotel introduced a new modern style and was imitated everywhere' ${ }^{67}$ To an extent, Eldem was right. The modernist building became a model for designing domestic space. Commenting on the impact of this project on Turkish design culture and on the education in the Fine Arts Academy, interior architect and educator Sadun Ersin stated that the Hilton was an important precedent, displaying a shift in the dominant taste. The faculty took students on field trips to the newly completed hotel to teach them how to design modern interiors. ${ }^{68}$

The massive white edifice, from the lobby to the bedrooms, was furnished in the modern style [8]. The Danish-American modern teakwood guest room furniture, finished with dark oil, was imported from England [9]. As an attempt to regionalize, the designers used local resources and artistry with touches of Orientalism to spice up the project for tourists [10]. ${ }^{69}$ In 1953, Architectural Record described the interiors as reconciliation between modern expression and Turkish cultural heritage and identity:

Mosques and minarets, and earlier native architecture of Istanbul, will one day soon be a scenic contrast to the latest American-aided project in the East, the Istanbul Hilton Hotel ... The picturesque quality of Turkish artistry will find its place in the interiors, even though the tourist have to take cabs to see the minarets. ${ }^{70}$

These interiors were credited to Eldem, the director of interior design Jane Kidder, and Davis Allen, acknowledged as 'the best interior designer' by Bunshaft. ${ }^{71}$ Ada Louise Huxtable, eminent architectural critic, wrote that components of design were not the 'artsy-craftsy decorative corn that is supposed to reflect local arts and does nothing but debase them' ${ }^{72}$ Some of the local accents included authentic puppet theatre figures in the Karagöz Bar, a domed ceiling decorated with abstract motifs extracted from Turkish carpets in the Marmara Bar and a vaulted ceiling in the Şadırvan dining room. ${ }^{73}$ Designated as the 'ladies' sitting room', the Tulip Room evoked an exotic image of a harem emphasizing the otherness of the orient for a Western audience. ${ }^{74}$ 
Fig 8. The lobby of the Istanbul Hilton Hotel furnished in the style of mid-twentieth century modern. Photograph: (c) Ezra Stoller/Esto

Fig 9. A typical guest room with English-made teak furniture. Photograph: (c) Ezra Stoller/Esto
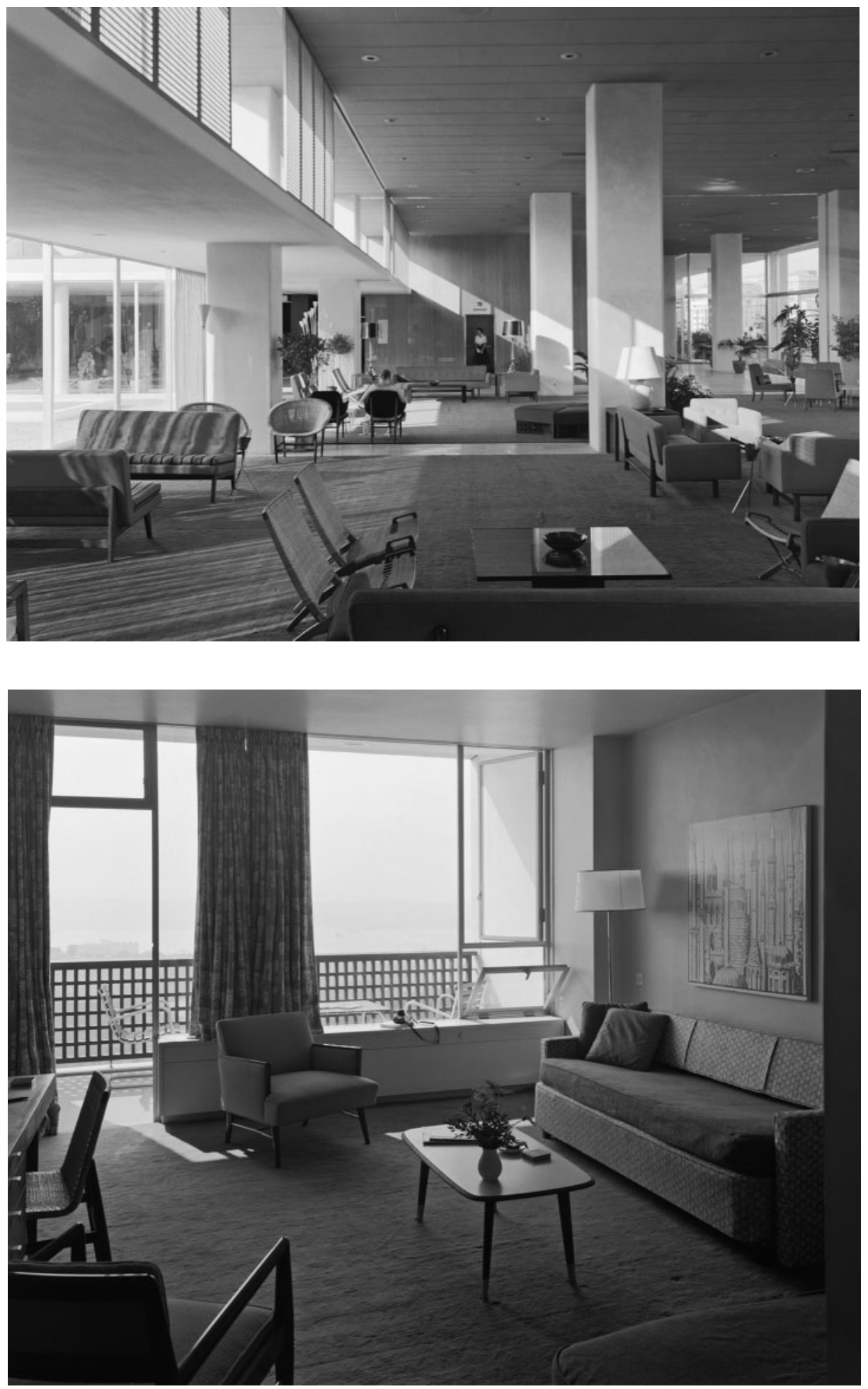

It was furnished with swags, low couches, ottomans with tasselled pillows, handpainted furniture and screens (kafes) of traditional Turkish design [11]. ${ }^{75}$ These details, which aimed to reconcile the modern décor and the traditional elements, simultaneously set the distinction between the contemporary and the retrogressive. 


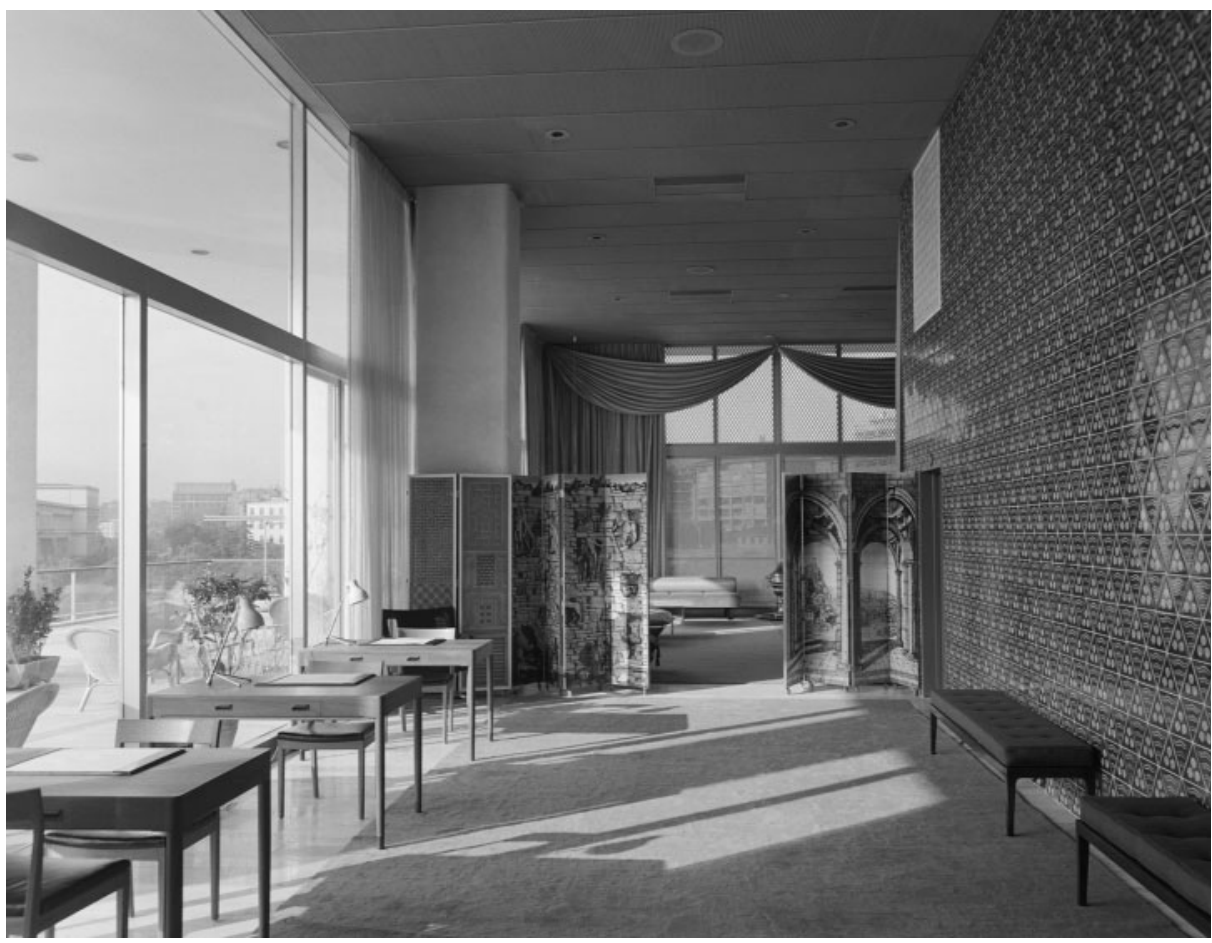

Fig 10. Tiled wall and use of local artistry with touches of Orientalism to spice up the project for the tourist simultaneously distinguished between the modern and the retrogressive.

Photograph: (c) Ezra Stoller/Esto

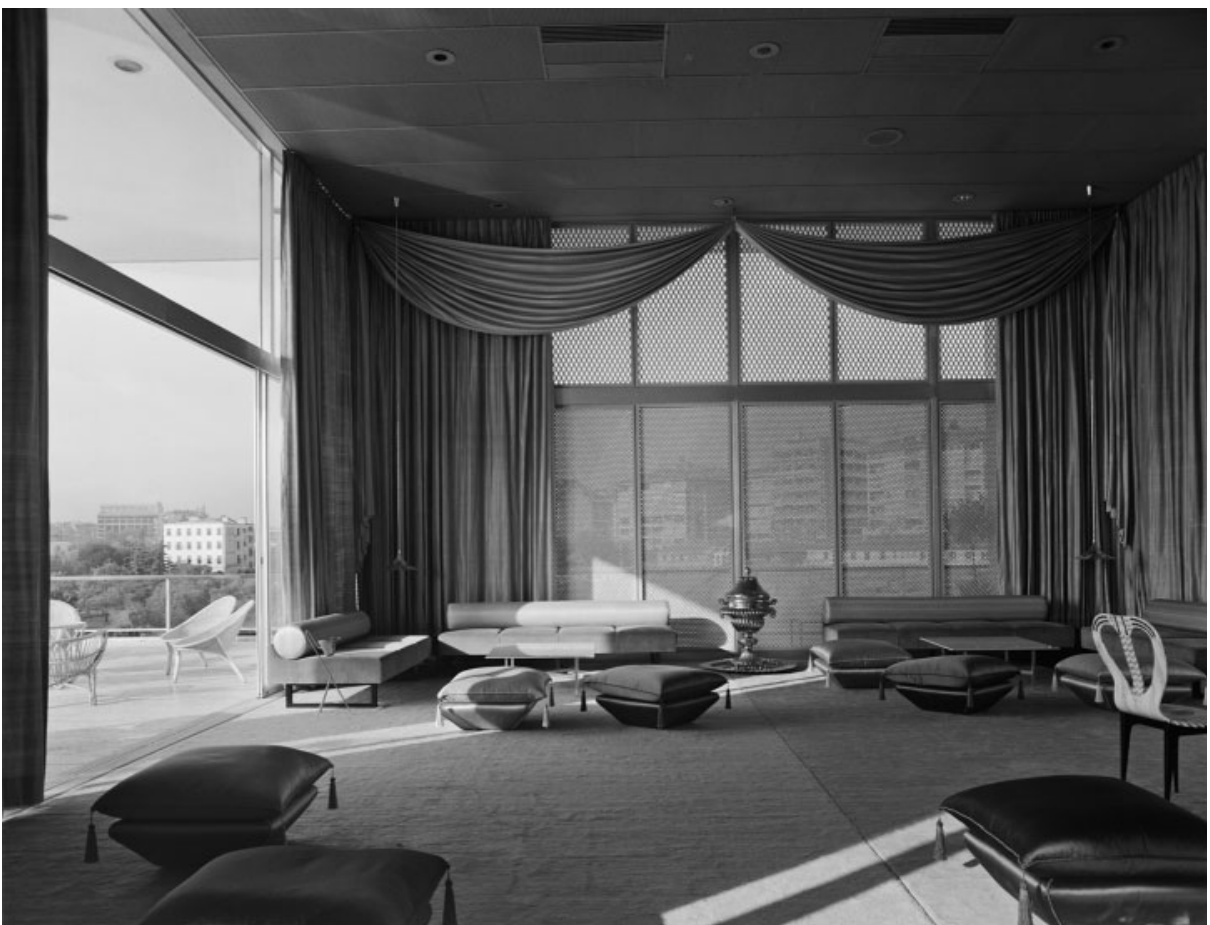

Fig 11. Low sofa in the Tulip Room reminiscent of the traditional sedir. Photograph: c) Ezra Stoller/Esto

The efforts to incorporate local accents into the modern scheme arguably exposed the dilemma of 'how to become modern'.76 On the one hand, the hotel was an 'ambassador' of the modern civilization; on the other hand, it portrayed the anxiety of cultivating a cultural past, because of its function as a tourist hotel. This tension, as articulated by Paul Ricoeur in the 1960s, suggested that 'in order to take part in modern 
civilization, it is necessary at the same time to take part in scientific, technical, and political rationality, something which very often requires the pure and simple abandon of a whole cultural past' ${ }^{\prime} 77$ For the Turkish audience, the hotel manifested aspirations for a new modern spirit. Nonetheless, this spirit cannot be linked directly to American architecture and design, nor can the formal and stylistic expression adopted by SOM, the American part of the collaboration. Both are products of European modernism disseminating from the United States after the Second World War. ${ }^{78}$ In this sense, a modern style did not connote a geographic West, that is, the United States or Europe, but represented a chronological West. Modern designs were promoted by many architects and designers and embraced by high-income groups as a way of living the modern way of life.

Not all Turkish elites went for the modern look. What was popularly called 'classical style', referring to furniture in historical European styles and antiques, still found appeal. Yet the modern emerged as a distinctive element, not just between different classes but also among upper-class consumers themselves and especially among those who moved to luxurious villas and prestigious apartment buildings constructed in metropolitan areas. 'My husband wanted to hire a decorator to furnish our new apartment', explained a resident. He hired a decorator from Istanbul to design their luxurious home in the upscale Kordon area of Izmir. 'The decorator used a modern style. Heavy furniture was not fashionable then ... He was very talented and knowledgeable about modern design'. ${ }^{79} \mathrm{~A}$ few pieces of family-owned antiques, such as the majestic portmanto (hallstand) with intricate carvings, and the bedroom set, could not be given up. But the rest of the residence was furnished in the mid-century modern style. Built-in shelf units, radiator covers and spatial dividers accompanied the unadorned furniture. Planar surfaces were finished with lacquer or natural wood laminates. Solid colours were preferred for upholstery and for rugs. Indirect cove illumination was used instead of chandeliers. Abstract art on walls, white tulle draperies on windows, light parquet floors and undecorated low white ceilings set a comforting ambiance for the furniture. Even the piano was a sleek object; the cherry wood furniture had a smooth finish with no hint of ornament. Completed in 1965, this modern home was a statement of stylish interior and furniture design. This statement was especially pronounced in the reception areas, where the inhabitants socialized and greeted their guests. As status symbols, modern furnishings verified the inhabitants' 'cultural competence', which was acquired by knowing about new trends, and adopting modern lifestyles that were informed by the latest developments in the Western sphere. ${ }^{80}$ The consumption of modern designs related to the idea of distinction as supremacy and empowerment.

\section{The 'American bar'}

As the United States came to symbolize progress and modernization, 'Americanization', as a formation that homogenized, had profound effects on the design culture. ${ }^{81}$ This conception can be observed in the inclusion of the 'American

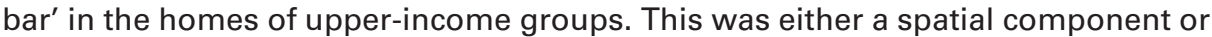
a piece of furniture. The former was composed of a counter with stools and a display of alcoholic beverages [12]. The latter was either freestanding furniture or a cabinet in a larger wall unit, where bottles and accessories were stored or displayed. The bar emerged as a popular design element for luxurious hotels, including the pivotal Istanbul Hilton Hotel, and the following the Grand Efes Hotel in Izmir (1958-1964) and the Grand Ankara Hotel (1958-1965). These hotels were fashionable places for socializing and for entertainment, not only for visitors but also for the elite residents of the cities in which they were built. The idea of socializing over alcoholic beverages was domesticated as the 'American bar' in luxurious homes. This was a spatial mechanism that regulated interaction. 

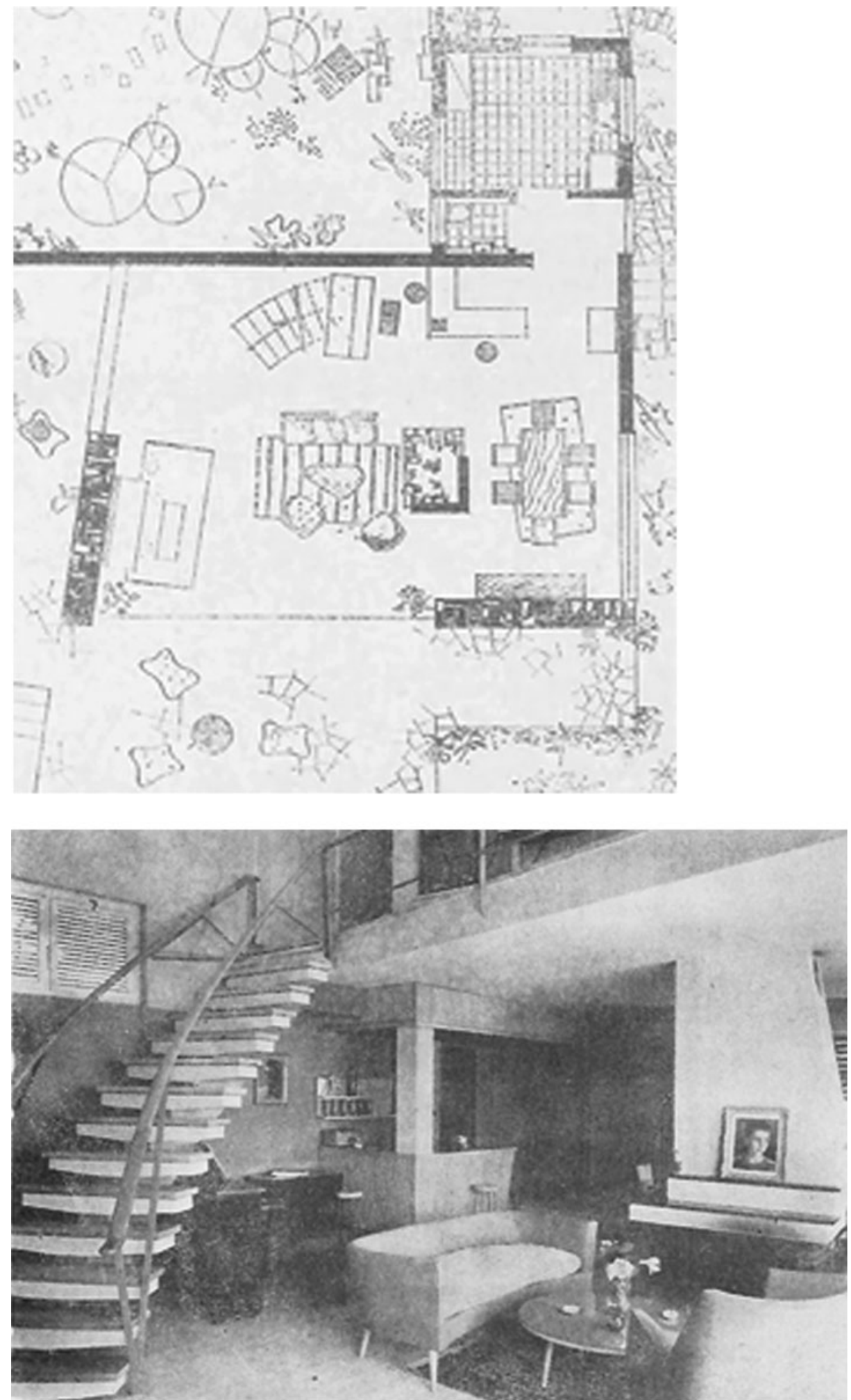

The 'American bar' as physical space prevailed in architect-designed residences. As one architect stated, 'During the 1950s throwing parties was popular and people needed a party space'. ${ }^{82} \mathrm{He}$ included an American bar in the roof terrace of the modern
Fig 12. An American bar with a counter and stools, inside a modern villa. The detached fireplace, next to which the sleek furniture is arranged, is typical of the 1950s and 1960s luxurious living areas. A piano, a status symbol since the late Ottoman era, is also included next to the bar. Arkitekt, no. 291, 1958, pp. $55-60$ 
apartment that he designed, to accommodate these emerging habits. Surely, the American bar demonstrated the dissemination of a mass urban culture through the entertainment industry and the media, but it also showed the homogenization that resulted from an anxiety that one would be perceived as the 'other'. ${ }^{83}$ The prevalence of the American bar exposed a desire for adopting habits associated with an exemplary lifestyle. Thus, it embodied a concern about being excluded from Western civilization and a desire not to be left behind.

The American bar was a pervasive spatial and decorative component, as a material objectification of social classification, throughout the 1970s. With respect to structure and agency, the American bar relates to Bourdieu's notion of habitus. Although Bourdieu does not directly link his theoretical notion of 'habitus', to the materiality of the home, where distinction is sought through aesthetic choices, he often makes references to its furnishings. ${ }^{84}$ Bourdieu explains, 'the habitus is not only a structuring structure, which organizes practices and the perception of practices, but also a structured structure: the principle of division into logical classes which organizes the perception of the social world is itself the product of internalisation of division into social classes' ${ }^{85}$ The American bar was a spatial structure that organized practices. It disciplined domestic entertainment in well-to-do households. It promoted serving and having a drink as a popular means of socializing and entertaining, for an urban culture. As the physical quality and size of the domestic bar changed, so did its practices. In some households, it often functioned as the centre of entertainment, regulating diverse interactions. In others, it primarily served as décor. The practices of the American bar varied, depending on the context, interpretation and social interface. Thus, the American bar was not just a hegemonic structure and a status symbol that practices were tailored to suit; rather, it was a medium through which inhabitants reproduced themselves as members of a socio-cultural group shaped by the changes of society in response to global dynamics, aspirations for modernity and the post-war American influence.

\section{Synthetic materials-Formica}

American influences were evident in the emergence of a Turkish market in synthetic materials and imported products. Post-war American domestic culture embraced synthetic materials as being easy to care for and attractive. Magazines including Life, Better Homes and Gardens and House Beautiful promoted plastics as the glamorized post-war housewives' and mothers' helpers in maintaining hygienic living conditions. Titled 'Plastics: A Way to a Better More Carefree Life', an issue of House Beautiful featured plastic wallpaper as an easily cleaned surface that enabled the housewife to live an 'elegant, carefree life' ${ }^{86}$ Architects and designers helped to popularize synthetic material in furniture design and textiles. Nylon, Orlon acrylic and Dacron polyester were promoted in draperies, upholstery and carpets. ${ }^{87}$

Images of synthetic materials travelled globally through such media as newspapers, magazines, movies and advertisements. American Venetian blinds and shades were marketed as new options to cover the large glass surfaces of contemporary buildings [13]. Artificial leather under the brand name of Vinylex was offered as a lowmaintenance and fashionable floor covering and upholstery for public and domestic interiors as well as for automobiles; it was also an inexpensive alternative to leather [14]. The public also saw colourful synthetic materials, such as Formica, in the homes of American officers, who lived in major centres for short periods. When they moved at the end of their term, the Americans sold their furniture to the locals. These found a market not simply because they filled the need for furniture but because they communicated a meaning: they were considered modern. ${ }^{88}$ Wallpaper, synthetic textiles, fibreboard and Formica were celebrated as the domestic products of a new era. Demand for these varied according to usability and social conventions. Yet, a chair 


\section{Denetian Blina}

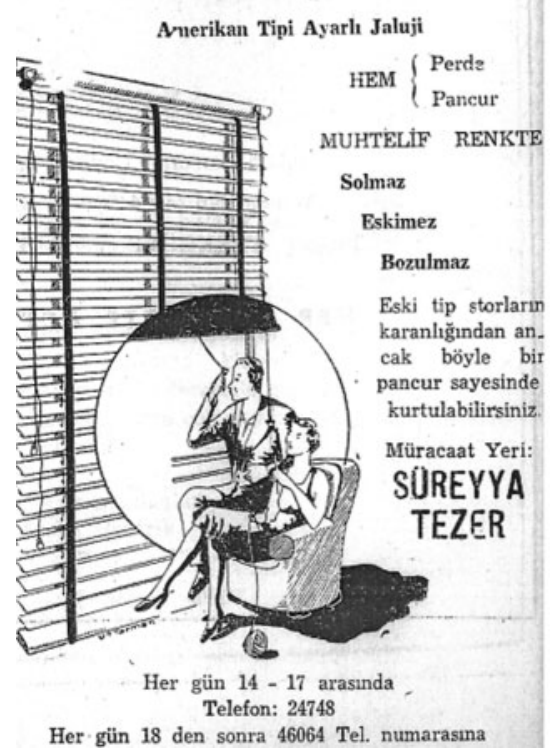

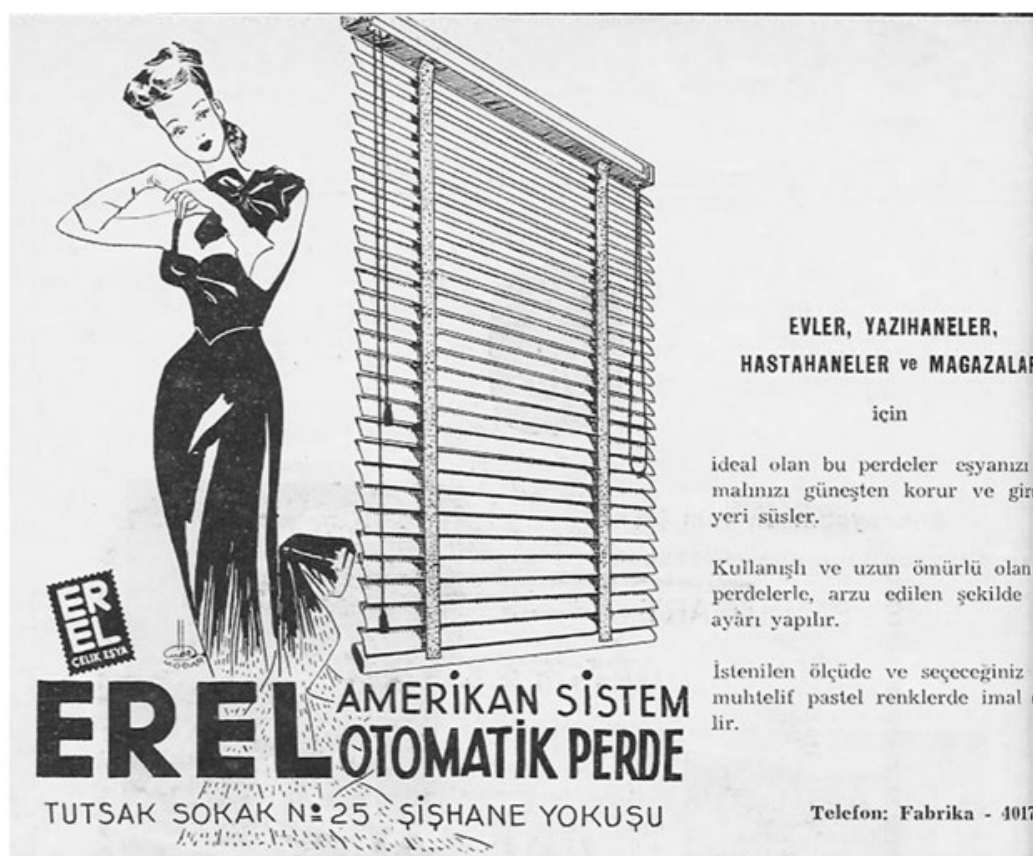

Fig 13. Advertisements for American Venetian blinds for domestic interiors during the 1950s. The 1950s issues of Arkitekt

The conceptualization of synthetic materials as modern reveals that the fundamental function of consumption is its capacity to make sense. This capacity reflects the power of consumption to communicate social meanings and to render the universe more intelligible to consumers. ${ }^{89}$ Products such as Formica, vinyl flooring, upholstery and synthetic fibres prevailed in contemporary interior and furniture designs, because they manifested progress and the change in taste in a global context. Their durable and hygienic properties appeared to surpass what used to be available in the market. ${ }^{90} \mathrm{~A}$ consumer recalled her preference for Formica furniture for its maintenance and durability:

I cannot forget the first time I saw a Formica table at my friend's house. He extinguished a cigarette on it. Nothing happened! He just dusted off the ashes. It looked as shiny and smooth as before. ${ }^{91}$

Formica came in different colours. Designers used it for making furniture and as accents for elaborating interiors. According to decorator Vedat Fer, the availability of new materials-chipboard, imitation wood sheets and Formica-changed the conception of stylish. ${ }^{92}$ Fer started using Formica in his atelier after 1957. Even though some designers dismissed Formica for looking cheap, many others saw it as 'state of the art'. An example of the latter was the use of a rose pink Formica dining table in the decoration of an upscale domestic interior by Bedia Bektaș, an interior designer trained in the United States. As one resident recalled, the decorator used new materials and bold colours:

Pink Formica was so daring! You would never think of using it inside an apartment. Yet, it looked so modern! Ms. Bedia used unusual colours and materials. The house was designed according to her wishes and guidance. ${ }^{93}$

Bektaş travelled to Izmir during her involvement with the decoration of the Grand Ephesus Hotel, which opened in 1964. This five-star luxury hotel was, for Izmir, what 

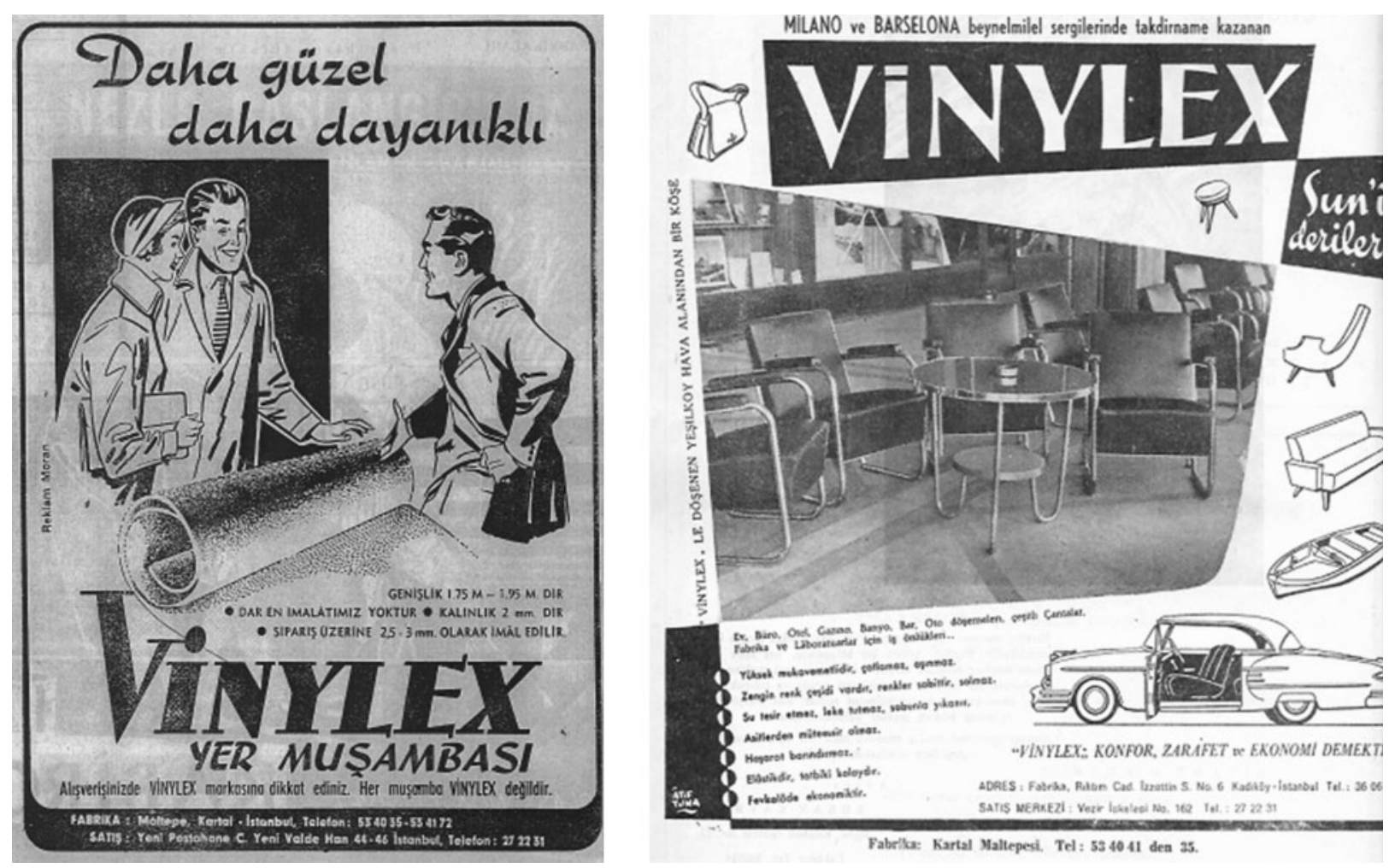

Fig 14. Advertisements for Vinylex during the 1950s. The 1950s issues of Arkitekt the Hilton was for Istanbul. ${ }^{94}$ Bektaş designed the entry hall and the living and dining areas of the modern apartment, which was built in 1961. These areas arguably displayed the clients' ‘cultural capital' and 'distinction', in Bourdieu's terminology, conveying their socio-cultural status associated with a cultivated group of people.

The eclectically styled old furniture that the family owned was given away when they moved to the new residence because it was considered inappropriate for the modern building. The new scheme included built-in furniture, such as the sideboard and a 'grass-green' upholstered seating element. The Turkish rug, a symbol of the orient, was abandoned as the usual floor covering and replaced by solid coloured rugs, custom woven according to Bektaş's instructions. The decorator used low couches that recalled the mid-century modern furniture designs of the Istanbul Hilton, inspired by the Turkish sedir, and matte dark walnut veneer as a contrast to the rose pink Formica tabletop. ${ }^{95}$ Describing the consumption of Formica furniture as 'modern', another consumer explained: 'We threw away our dear solid wood dining room set and replaced it with a dark Formica one. Now we regret it, but back then it was the thing to do' [15]. ${ }^{96}$ Formica's popularity diminished, as it did in the United States and Europe, in the 1970s. It came to be perceived as a cheap-looking material, ageing with cracks. Yet, before Formica was considered vulgar and inappropriate for fine interiors, it was sensible for consumers of different income levels, as a product of global development and as a material distinction of the modern.

\section{Conclusion}

Furnishings have played a significant role in internalizing a contemporary Western identity and defining the difference between the West and the orient: the past and the present in Turkey. Furniture choices signified the Western and urban cultural capital through which social distinction, shared ideals and group belonging were 
produced and secured. As such, well-made furniture was a commodity affordable to middle- and higher-income groups.

In the mid-twentieth century, modern designs were promoted as an affordable way to furnish domestic interiors. The unadorned style was embraced not only because it promised functional furniture massproduced at affordable prices but also because it embodied post-war ideas of modernization and correct living. Throughout the 1960s, the dominant taste in cosmopolitan areas was largely transformed through a replacement of historical styles with modern furniture, characterized by a sleek look, planar elements and new materials. These were especially emphasized in the status spaces where the residents entertained their guests. They served as an apparatus to indicate the inhabitants' cultural competence in modern lifestyles. Thus, the modern emerged as a strategy of distinction, not just between different classes but also within the upper class of consumers itself.

Architects and interior designers both promoted the taste reform towards modern furniture and educated

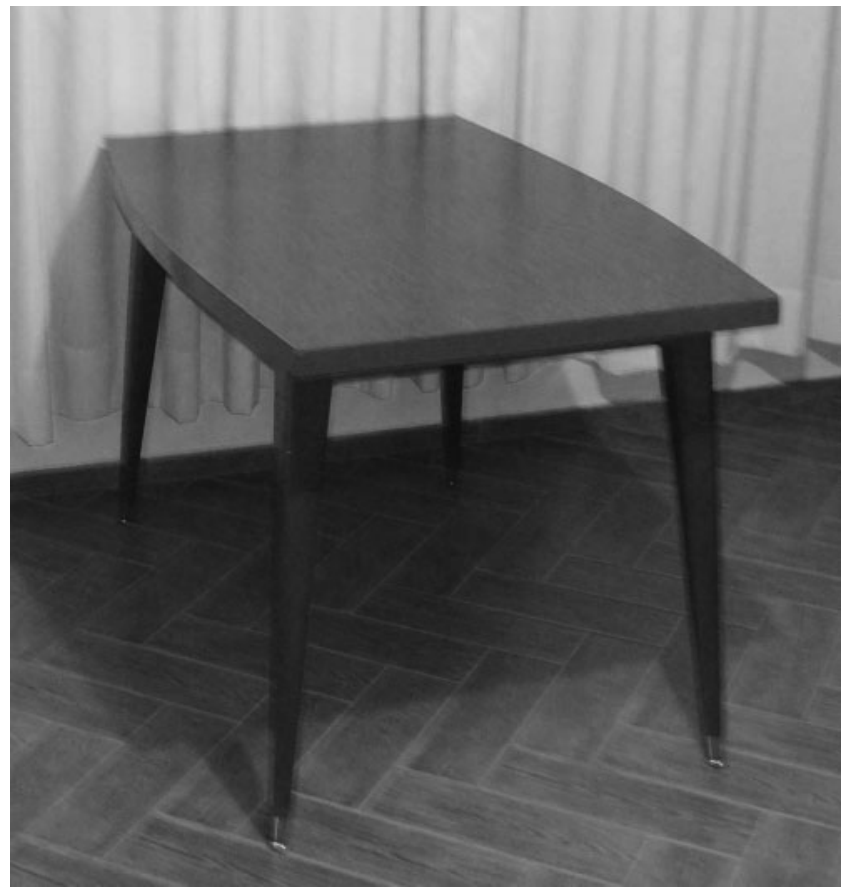
people in new lifestyles. The shift in the dominant taste disseminated through their designs, through the media and, significantly, through the emerging luxurious hotel projects, initiated by the government. The Istanbul Hilton Hotel was an influential

Fig 15. A Formica table bought in the early 1960s. Photograph precedent of a stylish post-war American culture as well as European modernism. The interior designs of this and the ensuing hotels had a profound impact in shaping the residential interiors and entertainment practices of a dominant class fraction. New spatial components and furniture, namely the American bar, served as a dynamic medium of distinction through which inhabitants reproduced themselves as members of an emerging global civilization, shaped by cold war dynamics. Simultaneously, their practices interpreted and contextualized the American influence.

American influence in domestic designs also appeared in the use of new synthetic materials, such as Formica, vinyl and nylon, by the latter part of the 1950s. These items mirrored an updated notion of the contemporary, which spread from the re-conceptualized West of the Cold War geopolitics. As American goods came to symbolize the West in the aftermath of the Second World War, so too, domestic ideals disseminating-but not necessarily originating and travelling direct-from the United States came to symbolize what was modern and progressive. Although the stylistic preferences of urban dwellers oscillated, inclinations towards a new modern style and the use of new materials undoubtedly had significant social, political and cultural implications. They marked a historical moment at a time when being modern and belonging to the Western sphere were of utmost importance in Turkish society. During this time, the nation enthusiastically participated in the Korean War (1951) and entered NATO (1953) to solidify military and political ties with the West. The materiality of furniture as a code was synonymous with a new modern identity. Connected to the redefinition of the West, modern designs were consumed as a strategy of distinction.

Meltem Ö. Gürel

Faculty of Art, Design \& Architecture, Bilkent University

mogurel@bilkent.edu.tr

If you have any comments to make in relation to this article, please go to the journal website on http://jdh.oxfordjournals.org and access this article. There is a facility on the site for sending email responses to the editorial board and other readers. 


\section{Notes}

1 M. Schapiro, 'Style', in Anthropology Today: An Encyclopedic Inventory, A. L. Kroeber (ed.), University of Chicago Press Chicago, 1953, p. 287. In his seminal work, Schapiro defined style as the constant form, qualities and expression in an individual's or a group's art. For a discussion of Schapiro's definition of style, also see D. Upton, 'Form and User: Style, Mode, Fashion, and the Artifact', in Living in a Material World: Canadian and American Approaches to Material Culture, G. L. Pocius (ed.), Institute of Social and Economic Research, Memorial University of Newfoundland, Canada, 1991, pp. 156-69.

2 Dell Upton writes, 'an ideological interpretation succeeds when its assumptions or propositions are made to seem self-evidentwhen they are transformed into common sense'. Referring to Antonio Gramsci's concept of 'hegemony', Upton argues that when this happens, these assumptions 'appear to be neutral depictions of the natural'. Upton, op. cit., p. 162. Also see A. Gramsci, Selections from the Prison Notebooks of Antonio Gramsci, International Publishers, New York, 1989, pp. 157-8.

3 P. Bourdieu, Distinction: A Social Critique of the Judgement of Taste, Harvard University Press, Cambridge, 1984, p. 170.

4 P. Bourdieu, Outline of a Theory of Practice, Cambridge University Press, Cambridge, 1977, p. 78.

5 Bourdieu, Distinction, op. cit.

6 Ottoman westernization arguably started at the beginning of the eighteenth century. The Treaty of Karlowitz (1699), marking the defeat of the Ottoman military in the Austro-Ottoman War of 1683-1697, signified the beginning of the Empire's decline. Following this treaty, Europe was considered an index of economic and military modernization.

7 Monumental massing combined under a single roof, symmetrical and axial composition resonating with Beaux-Art architectural conventions, and the use of Neoclassical, Baroque, Rococo and Empire style elements were characteristic of European palaces, rather than classical Ottoman precedents. I have argued elsewhere that despite these changes, the Dolmabahçe Palace can be considered authentically Ottoman, reflecting its own time and holding an in-between status between Western and traditional. M. Ö. Gürel, 'Dolmabahçe as Liminal Space', in Dolmabahçe Palace-150 Years Old International Symposium, K. Kahraman (ed.), TBMM Matbaası, Ankara, 2007, pp. 261-74.

8 Notably, while the adoption of Western furniture signals a shift in the perception of the West as economically, politically and militarily superior to the Ottoman State, it also indicates close ties with Europe. The words ottoman, sofa and divan reflect the Turkish influence and adoption of Turkish furniture in the West that began in the eighteenth century. Therefore, it would be a mistake to think of this as a one-way influence.

9 O. Boyla, 'Mobilya' [Furniture], Eczacıbașı Sanat Ansiklopedisi [Eczacıbașı Arts Encyclopedia], vol. 2, Yem Yayınları, Istanbul, 1997, pp. 1285-86.

10 Z. Çelik, The Remaking of Istanbul: Portrait of an Ottoman City in the Nineteenth Century, University of Washington Press, Seattle 1986 , p. 146

$11 \mathrm{U}$. Tanyeli, 'Westernization-Modernization in the Ottoman Wohnkultur. The Evolution of a New Set of Symbols', in Housing and Settlement in Anatolia-A Historical Perspective, Y. Sey (ed.), The History Foundation Publications, Istanbul, 1996, p. 285 and p. 288.

12 This was not 'an ethnic or socio-economic monolith' by any means. For example, Tanyeli refers to Moltke's description of an upper-class Armenian family's house in Istanbul. The interior looks quite like the home of a Muslim family. Tanyeli, op. cit., $p$. 287.

13 G. Ökçün, Osmanlı Sanayii [Ottoman industry], Sermaye Piyasası Kurulu, Ankara, 1997, pp. 116-19.

14 P. Dumont, 'Said Bey-The Everyday Life of an Istanbul Townsman at the Beginning of the Twentieth Century', in The Modern Middle East: A Reader, A. Hourani, P. S. Khoury \& M. C.
Wilson (eds.), University of California Press, Berkeley, 1993, p. 284.

15 As U. Tanyeli writes, the House Attendance book, taught in the fourth year of elementary school, listed things to be included in the reception and the entrance halls. The pictures to be hung on the walls were specified to be 'oil paintings and not pictures of family and friends'. Tanyeli, op. cit., pp. 297-6. Also see M. Celal, Ev Bakımı, İk Mektep-Sınıf 4 [House attendance-class 4] Istanbul, 1931-1932, p. 24 and p. 30. Life and Nature, prepared by Ahmed Cevad, showed images of interiors that were taken from French schoolbooks. A. Cevad, Hayat ve Tabiat [Life and nature], 2 volumes, Istanbul, 1928.

16 Z. Sayar, 'İç Kolonizasyon' [Internal colonization], Arkitekt, vol. 6 , no. 2, 1936, p. 47. Also see G. Baydar Nalbantoglu, 'Silent Interruptions: Urban Encounters with Rural Turkey', in Rethinking Modernity and National Identity in Turkey, S. Bozdoğan \& R. Kasaba (eds.), University of Washington Press, Seattle, 1997, p. 202. Unless otherwise noted, all translations are my own.

17 For a study of the 'cubic' house of the early republican culture as a means of modern living, see S. Bozdoğan, Modernism and Nation Building: Turkish Architectural Culture in the Early Republic, University of Washington Press, Seattle, 2001, chapter 5. For an earlier article of the same study, see S. Bozdoğan, 'Living Modern: The Cubic House in Early Republican Culture', in Housing and Settlement in Anatolia, op. cit., pp. 313-28.

18 Bozdoğan, Modernism and Nation Building, op. cit., pp. 203-4.

19 Arkitekt, all issues, 1935-1965.

20 A. Ziya, 'Binanın İçinde Mimar' [The architect inside the building], Mimar, vol. 1, no. 1, 1931, pp. 16-17.

21 C. E. Arseven, Yeni Mimari [New Architecture], Agah Sabri Kütüphanesi, Istanbul, 1931, pp. 30-2.

22 I use the terms interior architect/designer and decorator interchangeably throughout the text, because their popular conception was the same in the historical context.

23 S.. Uzunarslan, ‘Erken Cumhuriyet Dönemi Konutlarında Mekan ve Mobilya' [Space and furniture in the early republican period residences], Ph.D. thesis, Mimar Sinan University, 2002, pp. 107-8.

24 A. Mortaş, 'Film ve Dekor' [Film and decor], Mimar, no. 2, 1932, p. 48.

25 Y. K. Karaosmanoğlu, Ankara (first published 1934), İletișim Yayınları, Istanbul, 1997; M. S. Esendal, Ayașlı ile Kiracıları [Ayașıı and his tenants] (first published 1934) Dost Kitabevi, Ankara, 1957.

26 Karaosmanoğlu, op. cit., p. 137. This novel is heavily cited by researchers of early republican architecture. See Bozdoğan, Modernism and Nation Building, op. cit., p. 193; İ. Aslanoğlu, Erken Cumhuriyet Dönemi Mimarlığı [Early Republican Architecture], O.D.T.Ü. Mimarlık Fakültesi, Ankara, 2001, p. 86; A. Batur, 'To be Modern: Search for a Republican Architecture', in Modern Turkish Architecture, R. Holod \& A. Evin (eds.), University of Pennsylvania Press, Philadelphia, 1984, p. 77-8; A. Batur, '1925-1950 Döneminde Türkiye Mimarlığı' [Turkish Architecture in the Period of 1925-1950], in 75 Yılda Değișen Kent ve Mimarlık [75 Years of City and Architecture], Y. Sey (ed.), Tarih Vakfı, Istanbul, 1998, pp. 209-34. A Batur, 'Mimarlık' [Architecture], Cumhuriyet Dönemi Türkiye Ansiklopedisi [The Encyclopedia of the Turkish Republican Era], vol 5, İletișim Yayınları, Istanbul, 1983, p. 1388.

27 Bourdieu, Distinction, op. cit.

28 Bozdoğan, Modernism and Nation Building, op. cit., pp. 212-13. Uzunarslan, op. cit., pp. 103-4.

29 Karaosmanoğlu, op. cit., p. 137

30 For Marie Louis Sue's introductory lecture, see M. Cezar, 'Güzel Sanatlar Akademisi'nden 100. Yılda Mimar Sinan Üniversitesi'ne' [From Fine Arts Academy to Mimar Sinan University in 100 years], in Güzel Sanatlar Eğitiminde $100 \mathrm{Y}_{l} l$ [100 Years in Fine Arts Education], M. Giray (ed.), Mimar Sinan Üniversitesi Yayını, Istanbul, 1983, pp. 33-4; H. Münir, ‘Profesör Sue ve Tezyini Sanatlar' [Professor Sue and Decorative Arts], Yedigün, vol. 15 no. $368,1940, p p, 6-7 \cdot V$. Fer (a student of Sue), interview conducted by the author, Izmir, 31 December 2005. 
31 There were many reasons for this, including a reaction to the foreign architects practicing in Turkey and shortages of imported building materials caused by World War II. The beginning of the war was also important in evoking nationalist sentiments, even though Turkey did not participate in the war. The 'Seminar on National Architecture', established by Sedad Hakkı Eldem gave intellectual rigor to a systematic study of traditional Turkish architecture in the Academy. Nationalism in Turkish architecture found international support with foreign architects, such as Paul Bonatz.

32 For examples, see P. Kirkham, 'Humanizing Modernism: The Crafts, "Functioning Decoration" and the Eameses', Journal of Design History, vol. 11, no. 1, 1998, pp. 15-29; W. Rybczynski, Home: A Short History of an Idea, Viking, New York, 1986; C. Reed (ed.), Not at Home: The Suppression of Domesticity in Modern Art and Architecture, Thames and Hudson, London, 1996; L. Walker, 'Home Making: An Architectural Perspective', Signs, vol. 27, no. 3, 2002, pp. 823-35.

33 Bourdieu, Distinction, op. cit.

34 P. Sparke, 'Studying the Modern Home', The Journal of Architecture, vol. 9, no. 4, 2004, pp. 413-17.

35 Hayat, all issues, 1956-1965. Resimli Hayat, all issues, 1952-1956. Arkitekt, all issues, 1949-1965. My sources include oral histories and photographs of interiors in family albums.

36 For the role of this interaction in producing social and gender identities see M. Ö. Gürel, 'Defining and Living Out the Interior: The "Modern" Apartment and the "Urban" Housewife in Turkey during the 1950s and 1960s', Gender, Place \& Culture, in press.

37 O. Pamuk, Istanbul Hatıralar ve Şehir [Istanbul memories and the city], YKY, Istanbul, 2003, pp. 17-18.

38 Le Corbusier stated, 'The modern man and woman are bored at home; they go to night-clubs. But lesser folk who have no clubs gather together in the evening under the chandelier and hardly dare to walk through the labyrinth of their furniture which takes up the whole room and is all their fortune and their pride'. Declaring that 'old' furniture did not fit the living style of the 'modern' people, he continued, 'The existing plan of the dwellinghouse takes no account of man and is conceived as a furniture store. This scheme of things ... is of ill omen for society. It kills the spirit of the family, of the home ...' See Le Corbusier, Towards a New Architecture (first published 1923) Dover, New York, 1986, pp. 121-2.

39 W. Benjamin, 'Paris, Capital of the Nineteenth Century', in Reflections, P. Demetz (ed.), E. Jephcott (trans.), Schocken Books, New York, 1978, pp. 154-5.

40 M. Eminoğlu (ed.), Bir Beyoğlu Fotoromanı = A Beyoğlu PhotoRomance: 1870 Beyoğlu 2000, Yapı Kredi Yayınları, Istanbul, 2000, p. 143 and p. 211.

41 G. Scognamillo, Bir Levantenin Beyoğlu Anıları [A Levantine's Beyoğlu Memories], Metis Yayınları, Istanbul, 1990, p. 60 and p. 130.

42 S. H. Eldem, 'Elli Yıllık Cumhuriyet Mimarlığı' [Fifty Years of Republican Architecture], Mimarlık, no. 11-12, 1973, p. 10.

43 Y. Cem, 'Bir Mobilya Ustasının Ardından ...' [Remembering a furniture master...], published interview, Tasarım, no. 22, 1992, p. 108.

44 Z. Sayar, 'Mobilya Meselesi' [The Furniture Matter], Arkitekt, no. 219-220, 1950, p. 61

45 Ibid., pp. 61-3.

46 B. Koz, interview conducted by the author, Ankara, 1 May 2006. With her husband, Koz opened Butik $A$ in Ankara in 1959.

47 Interior architects S. Ersin, B. Koz and V. Fer, interviews conducted by the author, Istanbul, 5 May 2006, Ankara, 1 May 2006, and Izmir, 31 December 2005, respectively.

48 Among them were Nezih Eldem and Turgut Cansever. B. Koz, interview. Interior architect K. Şengül, interview conducted by the author, Ankara, 31 January 2006.

49 For examples, see 'Güzel Yuva' [Beautiful home] sections of the 1959 issues of Hayat magazine.
50 'Modern Ev Döșemek' [Furnishing the Modern Home], Resimli Hayat, no. 15, 1953, p. 21.

51 Le Corbusier, op. cit., p. 108 and p. 122

52 B. Colomina, 'The Media House', Assemblage, vol. 27, 1995, pp. 55-66. For studies on (post-war) model home designs see Journal of Architecture, vol. 9, no. 4, 2004. Modern model homes were exhibited in fairs, for example, Izmir International Fair; interviews by the author, Istanbul, 25 May 2006.

53 The Case Study House programme, spearheaded by John Entenza's Arts \& Architecture magazine from 1945 until 1966 is a well-known example of these efforts in the USA. E. Smith, Case Study Houses: The Complete CSH Program 1945-1966, Taschen, New York, 2002

54 Here, I also draw on semiotic interpretations of mode as discussed by Upton, op. cit., pp. 156-69.

55 This has been widely addressed in studies of Turkish architecture during the 1950s. See I. Tekeli, 'The Social Context of the Development of Architecture in Turkey', in Modern Turkish Architecture, op. cit., p. 24; M. Tapan, 'International Style: Liberalism in Architecture', in Modern Turkish Architecture, op. cit., pp. 105-18. Nonetheless, it should be noted that to the ordinary citizen, this distinction was not always important or clear.

56 C. Hilton, Be My Guest, Prentice Hall, New York, 1957, pp. 264-5.

57 International Hilton Hotels in general, and this project specifically have been interpreted as the United States' attempt to disseminate American values, beliefs, political ideals and living standards in the Cold War era. See A. J. Wharton, Building the Cold War: Hilton International Hotels and Modern Architecture, University of Chicago, Chicago, IL, 2001, introduction.

58 The Middle East Technical University (METU) was founded based on the American model in 1956. The first department to start teaching was architecture. This marked a change in Turkish architectural education. A. Yücel, ‘Pluralism Takes Command: The Turkish Architectural Scene Today', in Modern Turkish Architecture, op. cit., p. 122. For the US influence in industrial design education in this context see H. A. Er, F. Korkut and Ö. Er, U.S. Involvement in the Development of Design in the Periphery: The Case History of Industrial Design Education in Turkey 1950s-1970s', Design Issues, vol. 19, no. 2, 2003, pp. 17-34.

59 Hilton, op. cit., pp. 264-5.

60 'U.S. Architecture Abroad', Architectural Forum, no. 98, 1953, pp 101-15.

61 See 'Hotel in Istanbul', The Architectural Review, no. 118, 1955 pp. 290-96: 'Hilton's Newest Hotel' Architectural Forum, no. 103 1955, pp. 120-7; 'Commerce: New Markets', Architectural Forum, no. 102, 1955: 'Tourist Hotel for Istanbul, Turkey', Architectural Record, no. 113, 1953, cover and pp. 103-15; 'Hotel à Istanbul', L'Architecture d'aujourd'hui, no. 25, 1954, pp. 30-1; P. Bonatz, 'Hilton-Hotel, Istanbul', Baumeister, vol. 53, no. 8, 1956, pp. 53551, 567-9: 'Turistik Otel', [Touristic Hotel], Arkitekt, no. 243-4, 1952, cover and pp. 56-63.

62 'Hilton's Newest Hotel', op. cit., p. 120.

63 For International Style, as described by Henry-Russell Hitchcock and Philip Johnson in their 1932 book, concurrent with the groundbreaking Museum of Modern Art (MOMA) exhibition in New York see H. R. Hitchcock \& P. Johnson, The International Style: Architecture since 1922, W.W. Norton \& Co., New York, 1932

64 C. H. Krinsky, Gordon Bunshaft of Skidmore, Owings \& Merrill, MIT Press, Cambridge, Mass., 1988, p. 53. See also 'Tourist Hotel for Istanbul, Turkey', op. cit., p. 107.

65 For example, see C. S. Erce '26 Milyona Mal Olan Otel' [Hotel that Cost 26 Million], Resimli Hayat, no. 37, 1954, pp. 40-1; 'Hiltonda kadınlarla bașbașa' [Alone with Women in the Hilton], Hayat, no. 38, 1957, pp. 26-7; 'Geçen Cuma Hiltonda' [Last Friday at Hilton], Hayat, no. 72, 1958, p. 28.

66 The collective memory of the hotel as such was revealed by many during my interviews. The hotel as a favourite honeymoon location was mentioned by $\mathrm{Koz}$ in an interview. Also see A. O. Tan, 'Balayında Bal' [Honey in Honeymoon], Sofra, no. 1016, 2005. 
67 Eldem, op. cit., p. 10.

68 S. Ersin, interview. Ersin graduated from the Academy in 1950 and served as an educator (1955-1982), the head of the Decorative Arts Department (1963), the head of the Interior Architecture Department (1971), the rector of the Fine Arts Academy (1975 1978) and the dean of the Faculty of Industrial Arts (1978-1982).

69 The Teacher's Technical College in Ankara produced a considerable portion of the upholstered furniture under the supervision of the design office; the rest was imported from fourteen countries. Carpeting (covering 15,000 square yards) was hand woven in Konya, and cini tiles were produced in Kütahya. 'Hotel in Istanbul', op. cit., pp. 293-6. Also see Wharton, op. cit., p. 29.

70 'Tourist Hotel for Istanbul, Turkey', op. cit., pp. 103-4.

71 Krinsky, op. cit., p. 54. B. J. Blum, 'Chicago Architects Oral History Project: Natalie de Blois', in Chicago Architects Oral History Project Collection [online interview March 12, 13, 14, 15, 2002], Department of Architecture, Ryerson \& Burnham Archives [updated August 2004; cited 15 October 2004], available from go pher: http://www.artic.edu/aic/libraries/caohp/deblois.html. In an interview, Davis Allen stated: 'everyone believes that I did the interiors, which was not the case at all. It was hard to explain to the people in New York that I was designing landscaping, swimming pools and even Turkish towels and tiles'. Allen spent a couple of years in Istanbul overseeing the construction and the selection of materials and working in close proximity with Eldem. M. Slavin, Davis Allen: Forty Years of Interior Design at Skidmore, Owings \& Merrill, Rizzoli, New York, 1990, pp. 22-5.

72 A. L. Huxtable, 'A Personal Inquiry', Istanbul Hilton Magazine, no. 1,1970, p. 3 . This was previously printed in New York Times, 17 August 1969. See Krinsky, op. cit., p. 55.

73 'Hotel in Istanbul', op. cit., pp. 293-6.

74 Ibid. Also see Wharton, op. cit., p. 26; E. Akcan, 'Amerikanlașma ve endise: Istanbul Hilton Oteli [Americanisation and anxiety: Istanbul Hilton Hotel], Arredamento Mimarlık, no. 100+41, 2001, pp. 118.

75 'Hotel in Istanbul', op. cit., pp. 293-6.

76 For a discussion on culture and civilization, see K. Frampton, 'Towards a Critical Regionalism: Six Points for an Architecture of Resistance', in The Anti-Aesthetic: Essays on Postmodern Culture, Hal Foster (ed.), Bay Press, Port Townsend, 1983, pp. 16-30. Also see A. Colquhoun, 'The Concept of Regionalism', in Postcolonial Spaces, G. Baydar Nalbantoglu \& W. C. Thai (eds.) Princeton Press, New York, 1997, pp. 13-23.

77 P. Ricoeur, 'Universal Civilization and National Cultures', in History and Truth, C. A. Kelbley (trans.), Northwestern University Press, Evanston, 1965, pp. 276-7.

78 With the unfolding of the Second World War, prominent modern ists such as Mies van der Rohe and Walter Gropius relocated to the USA, making it a major hub from which a reinterpreted version of modern architecture spread. Henry-Russell Hitchcock, who had coined the term 'International Style' with Philip Johnson to describe interwar European modernism in 1932, declared, 'American architecture has come to occupy a position of special prominence in the world'. H. R. Hitchcock \& A. Drexler (eds.), Built in USA: Postwar Architecture, Simon \& Schuster, New York, 1952, p. 10.
79 Interview conducted by the author, Izmir, 13 May 2006.

80 As used by Bourdieu, 'cultural competence' relates to cultural capital or culturally based taste. Bourdieu, Distinction, op. cit., p. 170.

81 I use the term 'Americanization' as discussed by Jean-Louis Cohen. According to Cohen 'Americanization' is different from 'Americanism'. The latter is urged by incertitude and an anxiety about staying behind the new world. It has no fixed referent and has been an inspiration for architectural creation 'Americanization', on the other hand, is the transformation of the variety of ideas that constitute 'Americanism' into a symbol of America. J. L. Cohen, Scenes of the World to Come: European Architecture and the American Challenge, 1893-1960, Canadian Centre for Architecture, Montreal, 1995.

82 N. Ersin, interview conducted by the author, Ankara, 29 May 2006.

83 I use the term other with reference to E. Said, Orientalism Pantheon Books, New York, 1978.

84 Sparke, op. cit., p. 415.

85 Bourdieu, Distinction, op. cit., p. 170.

86 S. Phillips, 'Plastics', in Cold War Hothouses: Inventing Postwar Culture, from Cockpit to Playboy, B. Colomina, A. Brennan \& J. Kim (eds.), Princeton Architectural Press, New York, 2004, p. 98 ; 'Plastics: A Way to a Better More Carefree Life', House Beautiful, vol. 89 , no. 2,1947 , p. 120 and pp. 122-3.

87 R. L. Blaszczyk, 'Designing Synthetics, Promoting Brands: Dorothy Liebes, DuPont Fibres and Post-war American Interiors' Journal of Design History, vol. 21, no. 1, 2008, pp. 75-99.

88 A number of interviewees expressed this opinion. Interior architect B. Koz (interview) said that this was the common perception, but even so, some interior designers did not like Formica because it looked cheap.

89 M. Douglas \& B. Isherwood, The World of Goods: Towards an Anthropology of Consumption, Routledge, London and New York, 1996. For a similar argument, see C. Campbell, The Romantic Ethic and the Spirit of Modern Consumerism, B. Blackwell, Oxford, UK, 1987.

90 Plastics were promoted in architectural publications. See 'Plastik Nedir' [What is plastic], (trans. B. Yüngül from La Construction), Arkitekt, no. 227-228, 1950, pp. 244-5.

91 Interview conducted by the author, Izmir, 5 February 2006.

92 Fer, Interview.

93 Interview conducted by the author, Izmir, 17 October 2005.

94 Originally, the building was designed by the German architect Paul Bonatz, who had taught at Istanbul Technical University After his untimely death in 1956, Fatin Uran took up and finished the project. The interior architecture team was headed by Ernst Hürlimann, a Munich architect. 'Büyük Efes Oteli İzmir' [The Grand Ephesus Hotel-Izmir], Arkitekt, vol. 35, no. 318, 1965, pp. 5-13.

95 Interviews with three residents conducted by the author, Izmir, 17 October 2005; Izmir, 30 December 2005.

96 Interview conducted by the author, Izmir, 19 October 2005 